\title{
Intracellular Proteolysis of Progranulin Generates Stable, Lysosomal Granulins that Are Haploinsufficient in Patients with Frontotemporal Dementia Caused by GRN Mutations
}

[DChristopher J. Holler, ${ }^{1}$ Georgia Taylor, ${ }^{1}$ Qiudong Deng, ${ }^{1,2}$ and ${ }^{\circledR}$ Thomas Kukar ${ }^{1,3,4}$

DOI:http://dx.doi.org/10.1523/ENEURO.0100-17.2017

${ }^{1}$ Department of Pharmacology, Emory University School of Medicine, Atlanta, GA 30322, ${ }^{2}$ Department of Biochemistry, Emory University School of Medicine, Atlanta, GA 30322, ${ }^{3} \mathrm{Center}$ for Neurodegenerative Disease, Emory University School of Medicine, Atlanta, GA 30322, and ${ }^{4}$ Department of Neurology, Emory University School of Medicine, Atlanta, GA 30322

\section{Visual Abstract}

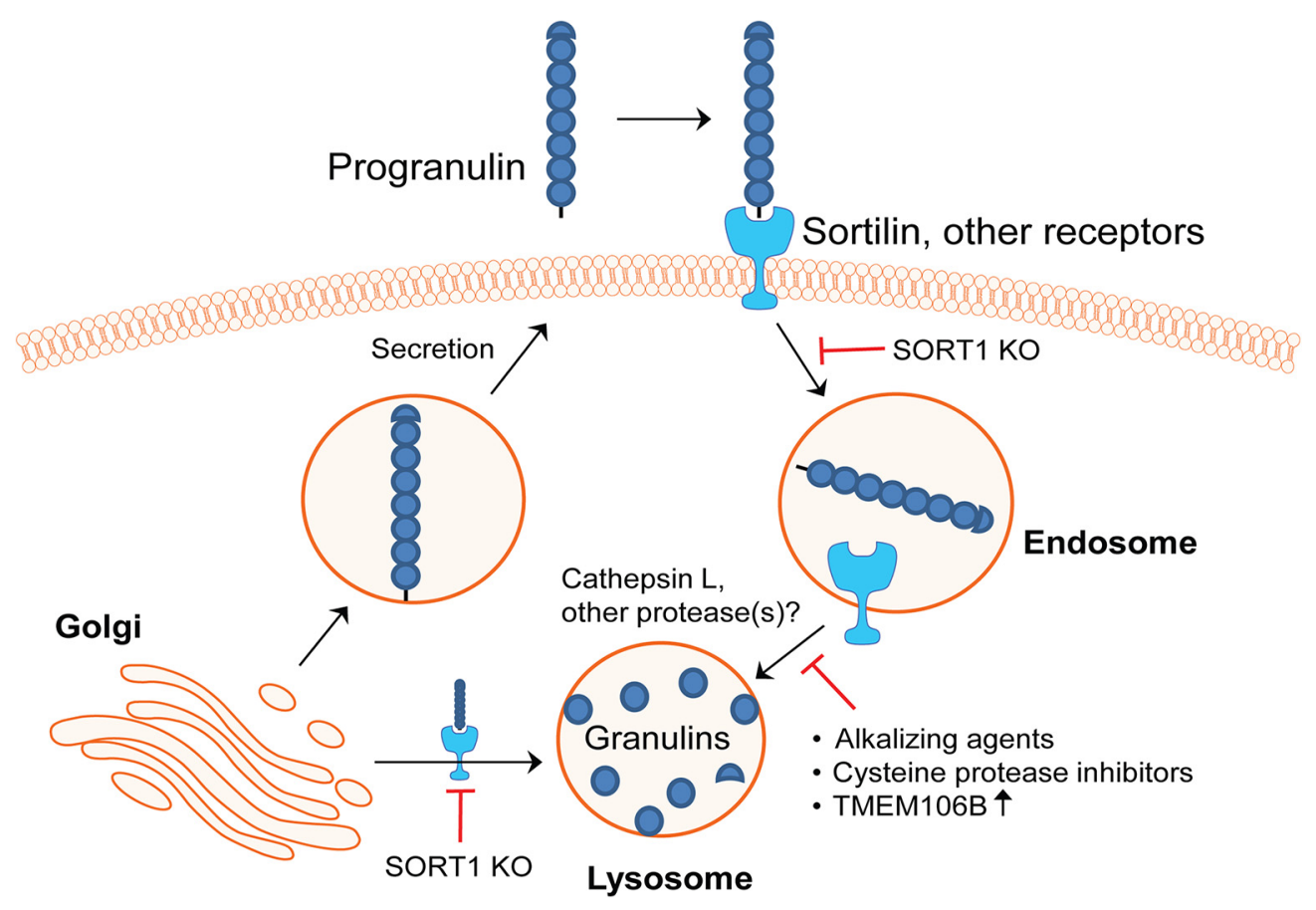

\section{Significance Statement}

Progranulin (PGRN) plays a critical, yet undefined role in lysosome function. PGRN is cleaved into 6-kDa proteins called granulins (GRNs), but this process is poorly understood. We find that PGRN is proteolytically processed into stable, lysosomal GRNs, implying that GRNs may have a functional role in the lysosome, and are not toxic as previously proposed. Moreover, deficiency of GRNs in frontotemporal dementia (FTD) caused by GRN mutations may play a causal role in the development of lysosome dysfunction that underlies FTD-GRN, which paves the way for testing GRN replacement as a therapeutic strategy. Finally, potential drug candidates to treat FTD-GRN should evaluate their effect on the production of both PGRN and GRNs in the brain. 
Homozygous or heterozygous mutations in the GRN gene, encoding progranulin (PGRN), cause neuronal ceroid lipofuscinosis (NCL) or frontotemporal dementia (FTD), respectively. NCL and FTD are characterized by lysosome dysfunction and neurodegeneration, indicating PGRN is important for lysosome homeostasis in the brain. PGRN is trafficked to the lysosome where its functional role is unknown. PGRN can be cleaved into seven 6-kDa proteins called granulins (GRNs); however, little is known about how GRNs are produced or if levels of GRNs are altered in FTD-GRN mutation carriers. Here, we report the identification and characterization of antibodies that reliably detect several human GRNs by immunoblot and immunocytochemistry. Using these tools, we find that endogenous GRNs are present within multiple cell lines and are constitutively produced. Further, extracellular PGRN is endocytosed and rapidly processed into stable GRNs within lysosomes. Processing of PGRN into GRNs is conserved between humans and mice and is modulated by sortilin expression and mediated by cysteine proteases (i.e. cathpesin L). Induced lysosome dysfunction caused by alkalizing agents or increased expression of transmembrane protein 106B (TMEM106B) inhibit processing of PGRN into GRNs. Finally, we find that multiple GRNs are haploinsufficient in primary fibroblasts and cortical brain tissue from FTD-GRN patients. Taken together, our findings raise the interesting possibility that GRNs carry out critical lysosomal functions and that loss of GRNs should be explored as an initiating factor in lysosomal dysfunction and neurodegeneration caused by GRN mutations.

Key words: Alzheimer's disease; amyotophic lateral sclerosis; autophagy; cathepsin L; frontotemporal dementia; granulins; lysosomal storage disease; neurodegeneration; neuroinflammation; neuronal ceroid lipofuscinosis; Parkinson's disease; progranulin

\section{Introduction}

Progranulin (PGRN) is a $\sim 88-k D a$ multifunctional, secreted glycoprotein that is ubiquitously expressed. PGRN has an important function in the brain, where it is expressed primarily in microglia and neurons (Suh et al., 2012; Uhlén et al., 2015; Zhang et al., 2016). Notably, PGRN is composed of seven $\sim 6-\mathrm{kDa}$ granulin (GRN)

Received March 22, 2017; accepted August 1, 2017; First published August 9, 2017.

The authors declare competing financial interests. A patent related to this work entitled "Methods to treat neurodegeneration with granulins" has been filed.

Author contributions: C.J.H. and T.K. designed research; C.J.H., G.T., Q.D., and T.K. performed research; C.J.H., G.T., Q.D., and T.K. analyzed data; C.J.H. and T.K. wrote the paper.

This work was supported by National Institutes of Health (NIH) Grants R00AG032362 and R01NS093362, a New Vision Award (Donors Cure Foundation), an Emory University Research Committee grant, the Emory Alzheimer's Disease Center Pilot Grant P50AG025688, the Alzheimer's Association New Investigator Research grant, the Association for Frontotemporal Degeneration, and the Bluefield Project to Cure Frontotemporal Dementia (T.K.). Q.D. and C.H. were supported by the NIH T32 Training Grant 2T32NS007480. Additional support was provided by the National Center for Advancing Translational Sciences of the National Institutes of Health under Award Number UL1TR000454. Research reported in this publication was supported in part by the Neuropathology Core, EICI, and EIPC of the Emory Neuroscience NINDS Core Facilities Grant, 5P30NS055077.

Acknowledgements: We thank $\mathrm{Dr}$. Fengua $\mathrm{Hu}$ for sharing the mCherryPGRN construct, Dr. Rosa Rademakers and Dr. Alexandra M. Nicholson for sharing TMEM106B constructs, Dr. Laura Reinholdt at The Jackson Laboratory for providing PGRN KO MEFs, Dr. Marla Gearing for providing postmortem brain tissue, Dr. Chadwick Hales for providing human fibroblasts, and Dr. Craig Heilman for making the Emory PGRN (4C1) antibody. We also thank custom cloning performed by Dr. Oskar Laur within the Emory Integrated Genomics Core (EIGC).

Correspondence should be addressed to Thomas Kukar, Ph.D., Department of Pharmacology, Emory University, 1510 Clifton Road, Suite 5123, Atlanta, GA 30322, E-mail: thomas.kukar@emory.edu.

DOI:http://dx.doi.org/10.1523/ENEURO.0100-17.2017

Copyright (C) 2017 Holler et al.

This is an open-access article distributed under the terms of the Creative Commons Attribution 4.0 International license, which permits unrestricted use, distribution and reproduction in any medium provided that the original work is properly attributed. proteins and one half-granulin protein termed paragranulin (para-GRN). Each GRN protein shares an evolutionary conserved cysteine-rich consensus motif and is folded into a similar structure stabilized by multiple disulfide bonds (Hrabal et al., 1996; Tolkatchev et al., 2008). Within PGRN, each GRN is joined by short linear sequences, termed linkers, which can be cleaved by proteolysis to release the mature GRN proteins (Zhu et al., 2002; Kessenbrock et al., 2008; Suh et al., 2012). The GRNs were originally named using letters (A-G plus para-GRN) when they were first discovered (Bateman et al., 1990). The consensus nomenclature (UniProtKB: P28799) refers to each GRN numerically according to their position within PGRN starting at the amino $(\mathrm{N})$ terminus as follows: para-GRN, GRN-1 (G), GRN-2 (F), GRN-3 (B), GRN-4 (A), GRN-5 (C), GRN-6 (D), GRN-7 (E). The functional roles of GRNs are unknown, in part, because specific antibodies to detect endogenous GRNs have not been available.

PGRN and GRNs came to the attention of the neuroscience field in 2006, when autosomal dominant mutations in the GRN gene were discovered as a common cause of frontotemporal dementia (FTD) with inclusions of the TAR DNA-binding protein 43 (TDP-43; Baker et al., 2006; Cruts et al., 2006; Gass et al., 2006). FTD is the most common type of dementia in people under 60 years of age and is the clinical term for a spectrum of incurable neurodegenerative diseases affecting the frontal and temporal lobes (Bang et al., 2015). GRN mutations cause FTD through haploinsufficiency or loss-of-function of PGRN (Ghidoni et al., 2012a; Kleinberger et al., 2013; Pottier et al., 2016). In FTD-GRN carriers, circulating PGRN levels are decreased by $\sim 50 \%$ in plasma and CSF (Finch et al., 2009; Ghidoni et al., 2012b; Meeter et al., 2016). However, it is unknown how GRN mutations affect levels of GRNs in the brain. Moreover, it is unclear why loss of PGRN in the brain causes neurodegeneration. 
One potential explanation, with increasing support, is that PGRN haploinsufficiency causes lysosome dysfunction (Sargeant, 2016). Lysosome dysfunction is a common occurrence in numerous neurodegenerative diseases (Platt et al., 2012; Martini-Stoica et al., 2016) and growing evidence indicates a critical role for PGRN in the maintenance of lysosome homeostasis (Ahmed et al., 2010; Smith et al., 2012; Götzl et al., 2014; Tanaka et al., 2014; Almeida et al., 2016; Lui et al., 2016). First, PGRN is associated with the lysosome based on proteomic, transcriptomic, and immunofluorescence studies (Kollmann et al., 2005; Hu et al., 2010; Settembre et al., 2011; Song et al., 2013; Gowrishankar et al., 2015). Further, a portion of PGRN can be trafficked to the lysosome through either a sortilin (SORT1; Hu et al., 2010)- or prosaposin (PSAP; Zhou et al., 2015)-dependent pathway. Additionally, humans with homozygous GRN mutations that make no PGRN develop a lysosomal storage disease called neuronal ceroid lipofuscinosis (NCL; Smith et al., 2012; Canafoglia et al., 2014; Almeida et al., 2016). Homozygous Grn knockout (KO) mice have defects similar to NCL including neuroinflammation, lipofuscin accumulation, and lysosome dysfunction (Ahmed et al., 2010; Wils et al., 2012; Götzl et al., 2014; Sargeant, 2016). Importantly, NCL-like lysosomal dysfunction and pathology has been observed in cells and brain tissue from heterozygous FTD-GRN patients (Götzl et al., 2014; Ward et al., 2017), suggesting a common underlying disease process. Finally, the transmembrane protein 106B (TMEM106B), a neuronal lysosomal protein that regulates lysosome transport and function, is a strong genetic risk factor for FTDGRN (Van Deerlin et al., 2010; Finch et al., 2011; Nicholson and Rademakers, 2016). Thus, determining how PGRN and GRNs affect lysosome function is critical to understanding the pathogenesis of diseases caused by GRN mutations.

GRNs were identified from extracts of cells and various tissues using large-scale biochemical fractionation over twenty years ago, yet are still poorly understood (Bateman et al., 1990; Shoyab et al., 1990; Belcourt et al., 1993). Previously, GRNs were proposed to be produced from extracellular PGRN, especially in inflammatory conditions (Zhu et al., 2002; Kessenbrock et al., 2008), although this has not been demonstrated in vivo. Alternatively, based on the emerging lysosomal role of PGRN, we hypothesized that GRNs are produced intracellular in the lysosome. Unfortunately, the lack of sensitive tools to detect GRNs has hampered the ability to test this idea. Here, we report for the first time, the identification and characterization of antibodies that reliably detect several human GRNs by immunoblot and immunocytochemistry. Using these tools, we have begun to dissect the intracellular production and localization of GRNs. Further, we provide evidence that multiple GRNs, like their precursor PGRN, are haploinsufficient in FTD-GRN mutation patients.

\section{Materials and Methods}

\section{Statistical analysis}

Details of the statistical analysis used for each experiment are listed in Table 1. All data are presented as the mean \pm SEM. An unpaired two-tailed Student's $t$ test was used to generate $p$ values for experiments where two groups were compared. One-way ANOVA was used followed by Dunnett's comparison post hoc test for comparisons of more than two groups. Statistical analyses were performed in GraphPad Prism 6.02 (GraphPad Software); $p<0.05$ was considered significant.

\section{Chemical reagents}

Bafilomycin A1 (BafA1) was from Tocris (R\&D Systems). The inhibitors Z-FA-fmk (cysteine protease) and Z-VADfmk (pan-caspase) were from Calbiochem (EMD Millipore) and BD PharMingen (BD Biosciences), respectively. Cathepsin L inhibitor II (Z-FY-CHO) and ALLN were from Calbiochem. Elastase inhibitor MeOSuc-AAPV-cmk (N(Methoxysuccinyl)-Ala-Ala-Pro-Val-chloromethyl ketone) and all other chemical inhibitors were from Sigma-Aldrich.

\section{Cloning of human GRN expression vectors}

The DNA sequences for individual GRNs were codon optimized and custom synthesized by GenScript. First, the amino acid sequence for human para-GRN and each GRN (1 through 7), including the linker region at the carboxyl (C)-terminal end was identified based on the Universal Protein Resource database (P287991; GRN_HUMAN; Table 2). The endogenous PGRN signal peptide (SP) sequence followed by a twin-Strep and FLAG tag was added to the $\mathrm{N}$ terminus of each GRN. Synthetic GRN gene constructs were designed to add a 5' Hindlll (AAGCTT) site, a Kozak sequence (GCCACC) before the ATG start codon, a 3' Stop codon, and a Xhol (TGACTCGAG) site. Following synthesis, each gene was inserted into the pcDNA3.1 $(+)$ vector using a Hindlll/Xhol cloning strategy. All constructs were verified using DNA sequencing, restriction digests, and PCR amplification. Subsequently, primers were designed for each GRN to remove the linker region; each construct was amplified via PCR, and subcloned into pcDNA3.1 (+) vector, and verified using DNA sequencing.

\section{Purification of recombinant PGRNs}

A tandem affinity purification (TAP) tag was cloned onto the $\mathrm{C}$ terminus or $\mathrm{N}$ terminus of full-length human PGRN to generate C-TAP PGRN or N-TAP PGRN. C-TAP PGRN contains a twin-Strep tag followed by the FLAG epitope. N-TAP PGRN contains a twin Strep tag followed by a V5 epitope tag inserted following the endogenous PGRN signal peptide sequence. Stable HEK 293T cell lines overexpressing either C-TAP PGRN or N-TAP PGRN were generated. Stable cells were cultured and maintained in DMEM that contained $100 \mu \mathrm{g} / \mathrm{ml}$ Zeocin (Life Technologies/Thermo Fisher) and conditioned media were collected. PGRN was affinity purified from conditioned media over Strep-Tactin XT Superflow (catalog 2-4010-025) resin using a slightly modified protocol as described by the manufacturer (IBA GmbH). The mCherry-PGRN construct has been described (Hu et al., 2010). HEK Expi293 cells (RRID:CVCL_D615) were transfected with the mCherry-PGRN construct and conditioned media were collected following the manufacturer's protocol (Thermo Fisher; catalog A14635). mCherry-PGRN contains a poly- 
Table 1. Statistical analysis

\begin{tabular}{|c|c|c|c|c|}
\hline Figure & $\begin{array}{l}\text { Structure of the } \\
\text { data }\end{array}$ & Type of test & $p$ value & $95 \%$ confidence intervals \\
\hline $\begin{array}{l}\text { Fig. } 6 \mathrm{C} \text {, intracellular PGRN in WT vs SORT1-KO lysates }(n=3 \\
\text { independent replicates) }\end{array}$ & Normal distribution & Unpaired $t$ test & $p=0.0196$ & 30.13 to 198.5 \\
\hline $\begin{array}{l}\text { Fig. } 6 \mathrm{D} \text {, intracellular GRN-2,3 in WT vs SORT1-KO lysates }(n=3 \\
\text { independent replicates) }\end{array}$ & Normal distribution & Unpaired $t$ test & $p=0.0486$ & -93.93 to -0.4729 \\
\hline $\begin{array}{l}\text { Fig. } 6 G \text {, intracellular PGRN in TMEM106B-expressing HeLa lysates } \\
(n=3 \text { independent replicates) }\end{array}$ & Normal distribution & Unpaired $t$ test & $p=0.0005$ & 91.99 to 157.9 \\
\hline $\begin{array}{l}\text { Fig. } 6 H \text {, intracellular GRN-2,3 in TMEM106B-expressing HeLa } \\
\text { lysates ( } n=3 \text { independent replicates) }\end{array}$ & Normal distribution & Unpaired $t$ test & $p=0.0426$ & -134.8 to -3.742 \\
\hline $\begin{array}{l}\text { Fig. 6I, secreted PGRN in TMEM106B-expressing HeLa cell media } \\
(n=3 \text { independent replicates })\end{array}$ & Normal distribution & Unpaired $t$ test & $p=0.4803$ & -25.64 to 45.58 \\
\hline $\begin{array}{l}\text { Fig. } 6 L \text {, intracellular PGRN in TMEM106B-expressing PGRN KO } \\
\text { cells pulsed with PGRN ( } n=3 \text { independent replicates) }\end{array}$ & Normal distribution & Unpaired $t$ test & $p=0.0055$ & 36.84 to 113.6 \\
\hline $\begin{array}{l}\text { Fig. } 6 M \text {, intracellular GRN-2,3 in TMEM106B-expressing PGRN KO } \\
\text { cells pulsed with PGRN ( } n=3 \text { independent replicates) }\end{array}$ & Normal distribution & Unpaired $t$ test & $p=0.0282$ & -107.5 to -10.32 \\
\hline $\begin{array}{l}\text { Fig. 7A, secreted PGRN in treated HAP1 cell media }(n=3 \\
\text { independent replicates) }\end{array}$ & Normal distribution & One-way ANOVA & $\begin{aligned} p= & 0.0009, p<0.0001 \\
& p<0.0001\end{aligned}$ & $\begin{array}{l}-602.5 \text { to }-207.5 ;-1774 \text { to } \\
-1380 ;-1865 \text { to }-1471\end{array}$ \\
\hline $\begin{array}{l}\text { Fig. 7C, intracellular PGRN in treated HAP1 cell lysates }(n=3 \\
\text { independent replicates) }\end{array}$ & Normal distribution & One-way ANOVA & $\begin{array}{l}p=0.0007, p=0.0332 \\
\quad p=0.0151\end{array}$ & $\begin{array}{r}-417.2 \text { to }-153.8 ;-276.1 \text { to } \\
-12.74 ;-301.2 \text { to }-37.84\end{array}$ \\
\hline $\begin{array}{l}\text { Fig. } 7 D \text {, intracellular GRN-2,3 in treated HAP1 cell lysates }(n=3 \\
\text { independent replicates) }\end{array}$ & Normal distribution & One-way ANOVA & $\begin{array}{l}p<0.0001 \text { for all } 3 \\
\text { treatments }\end{array}$ & $\begin{array}{l}62.35 \text { to } 104.7 ; 65.25 \text { to } 107.6 \\
56.25 \text { to } 98.55\end{array}$ \\
\hline $\begin{array}{l}\text { Fig. } 71 \text {, intracellular PGRN in cathepsin L inhibitor-treated HAP1 cell } \\
\text { lysates ( } n=3 \text { independent replicates) }\end{array}$ & Normal distribution & One-way ANOVA & $\begin{array}{l}p>0.9999, p=0.5501 \\
\quad p=0.1055\end{array}$ & $\begin{array}{l}-39.01 \text { to } 37.81 ;-54.91 \text { to } 21.91 ; \\
-70.11 \text { to } 6.712\end{array}$ \\
\hline $\begin{array}{l}\text { Fig. } 7 J \text {, intracellular GRN-2,3 in cathepsin L inhibitor-treated HAP1 } \\
\text { cell lysates ( } n=3 \text { independent replicates) }\end{array}$ & Normal distribution & One-way ANOVA & $\begin{array}{l}p=0.2116, p=0.0144 \\
p=0.0003\end{array}$ & $\begin{array}{l}62.35 \text { to } 104.7 ; 65.25 \text { to } 107.6 \\
56.25 \text { to } 98.55\end{array}$ \\
\hline $\begin{array}{l}\text { Fig. 9B, intracellular PGRN in human fibroblasts ( } 3 \text { independent } \\
\text { patient lines for control and FTD-GRM) }\end{array}$ & Normal distribution & Unpaired $t$ test & $p=0.0030$ & -71.47 to -28.33 \\
\hline $\begin{array}{l}\text { Fig. } 9 \mathrm{C} \text {, intracellular GRN-2,3 in human fibroblasts ( } 3 \text { independent } \\
\text { patient lines for control and FTD-GRN) }\end{array}$ & Normal distribution & Unpaired $t$ test & $p=0.0023$ & -75.34 to -31.98 \\
\hline $\begin{array}{l}\text { Fig. } 9 D \text {, intracellular GRN-4 in human fibroblasts ( } 3 \text { independent } \\
\text { patient lines for control and FTD-GRN) }\end{array}$ & Normal distribution & Unpaired $t$ test & $p=0.0176$ & -90.57 to -15.19 \\
\hline $\begin{array}{l}\text { Fig. } 9 \mathrm{~F}, \mathrm{GRN}-2,3 \text { expression in human brain tissue ( } 5 \text { independent } \\
\text { patient samples for control and FTD-GRM) }\end{array}$ & Normal distribution & Unpaired $t$ test & $p=0.0123$ & -106.3 to -17.49 \\
\hline $\begin{array}{l}\text { Fig. } 9 G \text {, GRN- } 4 \text { expression in human brain tissue ( } 5 \text { independent } \\
\text { patient samples for control and FTD-GRN) }\end{array}$ & Normal distribution & Unpaired $t$ test & $p=0.0005$ & -83.70 to -35.11 \\
\hline $\begin{array}{l}\text { Fig. } 9 H \text {, PGRN expression by ELISA in human brain tissue ( } 5 \\
\text { independent patient samples for control and FTD-GRN) }\end{array}$ & Normal distribution & Unpaired $t$ test & $p=0.0403$ & -78.11 to -2.261 \\
\hline
\end{tabular}

histidine tag and was purified from the media over a cOmplete His-Tag column following manufacturer's protocol (Sigma-Aldrich; catalog 05893682001). For all purifications, the elutions containing recombinant PGRNs were concentrated and desalted into PBS using Vivaspin 500 Protein Concentrators [molecular weight (MW) cutoff 50 kDa; catalog 28932218; GE Healthcare Life Sciences]. The purity of recombinant PGRN was assessed by SDSPAGE followed by colloidal coomassie dye G-250 protein stain (GelCode Blue; Thermo Fisher) and estimated to be $>95 \%$ pure.

\section{Cell culture}

HeLa (human cervix carcinoma; American Type Culture Collection; ATCC), HEK293T (human embryonic kidney; ATCC; catalog CRL-3216, RRID:CVCL_0063 RRID), H4 (human neuroglioma; ATCC; RRID:CVCL_1239), and HEK293T cells stably expressing N-TAP PGRN (HEKPGRN) were cultured in high glucose DMEM supplemented with $10 \%$ FBS, $1 \%$ penicillin/streptomycin, and 1\% GlutaMax (Life Technologies). SH-SY5Y (human neuroblastoma; ATCC; catalog CRL-2266, RRID:CVCL_0019) and SW-13 (human adrenal cortical adenocarcinoma; ATCC) cells were cultured in DMEM/Ham's F12 1:1 medium supplemented with 10\% FBS and 1\% penicillin/ streptomycin. The near-haploid human cell line HAP1
(RRID:CVCL_Y019) has been previously described (Essletzbichler et al., 2014). The GRN KO (PGRN KO) HAP1 cell line (HZGHC004031c006) was produced using CRISPR/Cas9 gene editing to introduce a frame shift mutation into the coding sequence (10bp deletion in exon 2) of GRN (Horizon Discovery). The SORT1 KO (SORT1 KO) HAP1 cell line (HZGHC001782c010) was produced using CRISPR/Cas9 gene editing to introduce a frame shift mutation into the coding sequence (1bp insertion in exon 5) of SORT1 (Horizon Discovery). HAP1 cells were cultured in Iscove's modified Dulbecco's medium supplemented with $10 \% \mathrm{FBS}$ and $1 \%$ penicillin/streptomycin. The Grn KO (PGRN KO) mouse embryonic fibroblast (MEF) cells were generated and kindly provided by Dr. Laura Reinholdt at The Jackson Laboratory and cultured in DMEM supplemented with $10 \%$ FBS, $1 \%$ penicillin/ streptomycin, and 1\% GlutaMax. Primary human fibroblasts from control and FTD-GRN patients were collected by skin punch biopsy and cultured under standard published protocols.

\section{Transfections}

HEK293T cells or HAP1 PGRN KO cells were cultured as above in six-well dishes and transfected with $2 \mu \mathrm{g}$ of plasmid DNA (empty vector or GRN constructs \pm linkers) using Mirus LT1 transfection reagent (Mirus Bio, LLC) 
Table 2. Human GRN expression constructs

\begin{tabular}{|c|c|}
\hline Construct & Amino acid sequence \\
\hline $\begin{array}{l}\text { Para-GRN + } \\
\text { linker-1 }\end{array}$ & $\begin{array}{l}\text { MWTLVSWVALTAGLVAGSAWSHPQFEKGGGSGGGSGGSAWSHPQFEKGASDYKDDDDKTRCPDGQFCPVACCLD } \\
\text { PGGASYSCCRPLLDKWPTTLSRHL }\end{array}$ \\
\hline $\begin{array}{l}\text { Granulin-1 + } \\
\text { linker } 2\end{array}$ & $\begin{array}{l}\text { MWTLVSWVALTAGLVAGSAWSHPQFEKGGGSGGGSGGSAWSHPQFEKGASDYKDDDDKGGPCQVDAHCSAGHSCI } \\
\text { FTVSGTSSCCPFPEAVACGDGHHCCPRGFHCSADGRSCFQRSGNNSVG }\end{array}$ \\
\hline $\begin{array}{l}\text { Granulin-2 + } \\
\text { linker } 3\end{array}$ & $\begin{array}{l}\text { MWTLVSWVALTAGLVAGSAWSHPQFEKGGGSGGGSGGSAWSHPQFEKGASDYKDDDDKAIQCPDSQFECPDFSTC } \\
\text { CVMVDGSWGCCPMPQASCCEDRVHCCPHGAFCDLVHTRCITPTGTHPLAKKLPAQRTNRAVALSS }\end{array}$ \\
\hline $\begin{array}{l}\text { Granulin-3 + } \\
\quad \text { linker } 4\end{array}$ & $\begin{array}{l}\text { MWTLVSWVALTAGLVAGSAWSHPQFEKGGGSGGGSGGSAWSHPQFEKGASDYKDDDDKSVMCPDARSRCPDGSTC } \\
\text { CELPSGKYGCCPMPNATCCSDHLHCCPQDTVCDLIQSKCLSKENATTDLLTKLPAHTVG }\end{array}$ \\
\hline $\begin{array}{l}\text { Granulin-4 + } \\
\quad \text { linker } 5\end{array}$ & $\begin{array}{l}\text { MWTLVSWVALTAGLVAGSAWSHPQFEKGGGSGGGSGGSAWSHPQFEKGASDYKDDDDKDVKCDMEVSCPDGYTCC } \\
\text { RLQSGAWGCCPFTQAVCCEDHIHCCPAGFTCDTQKGTCEQGPHQVPWMEKAPAHLSLPDPQALKR }\end{array}$ \\
\hline $\begin{array}{l}\text { Granulin-5 + } \\
\quad \text { linker } 6\end{array}$ & $\begin{array}{l}\text { MWTLVSWVALTAGLVAGSAWSHPQFEKGGGSGGGSGGSAWSHPQFEKGASDYKDDDDKDVPCDNVSSCPSSDTCC } \\
\text { QLTSGEWGCCPIPEAVCCSDHQHCCPQGYTCVAEGQCQRGSEIVAGLEKMPARRASLSHPR }\end{array}$ \\
\hline $\begin{array}{l}\text { Granulin-6 + } \\
\quad \text { linker } 7\end{array}$ & $\begin{array}{l}\text { MWTLVSWVALTAGLVAGSAWSHPQFEKGGGSGGGSGGSAWSHPQFEKGASDYKDDDDKDIGCDQHTSCPVGQTCC } \\
\text { PSLGGSWACCQLPHAVCCEDRQHCCPAGYTCNVKARSCEKEVVSAQPATFLARSPHVGVK }\end{array}$ \\
\hline $\begin{array}{l}\text { Granulin-7 + } \\
\text { linker } 8\end{array}$ & $\begin{array}{l}\text { MWTLVSWVALTAGLVAGSAWSHPQFEKGGGSGGGSGGSAWSHPQFEKGASDYKDDDDKDVECGEGHFCHDNQTCC } \\
\text { RDNRQGWACCPYRQGVCCADRRHCCPAGFRCAARGTKCLRREAPRWDAPLRDPALRQLL }\end{array}$ \\
\hline $\begin{array}{l}\text { Para-GRN - } \\
\text { linker-1 }\end{array}$ & $\begin{array}{l}\text { MWTLVSWVALTAGLVAGSAWSHPQFEKGGGSGGGSGGSAWSHPQFEKGASDYKDDDDKTRCPDGQFCPVACCLD } \\
\text { PGGASYSCCRPLLD }\end{array}$ \\
\hline $\begin{array}{l}\text { Granulin-1 - } \\
\text { linker } 2\end{array}$ & $\begin{array}{l}\text { MWTLVSWVALTAGLVAGSAWSHPQFEKGGGSGGGSGGSAWSHPQFEKGASDYKDDDDKGGPCQVDAHCSAGHSC } \\
\text { IFTVSGTSSCCPFPEAVACGDGHHCCPRGFHCSADGRSCFQ }\end{array}$ \\
\hline $\begin{array}{l}\text { Granulin-2 - } \\
\quad \text { linker } 3\end{array}$ & $\begin{array}{l}\text { MWTLVSWVALTAGLVAGSAWSHPQFEKGGGSGGGSGGSAWSHPQFEKGASDYKDDDDKAIQCPDSQFECPDFST } \\
\text { CCVMVDGSWGCCPMPQASCCEDRVHCCPHGAFCDLVHTRCIT }\end{array}$ \\
\hline $\begin{array}{l}\text { Granulin-3 - } \\
\quad \text { linker } 4\end{array}$ & $\begin{array}{l}\text { MWTLVSWVALTAGLVAGSAWSHPQFEKGGGSGGGSGGSAWSHPQFEKGASDYKDDDDKSVMCPDARSRCPDGST } \\
\text { CCELPSGKYGCCPMPNATCCSDHLHCCPQDTVCDLIQSKCLS }\end{array}$ \\
\hline $\begin{array}{l}\text { Granulin-4 - } \\
\quad \text { linker } 5\end{array}$ & $\begin{array}{l}\text { MWTLVSWVALTAGLVAGSAWSHPQFEKGGGSGGGSGGSAWSHPQFEKGASDYKDDDDKDVKCDMEVSCPDGYTCC } \\
\text { RLQSGAWGCCPFTQAVCCEDHIHCCPAGFTCDTQKGTCEQ }\end{array}$ \\
\hline $\begin{array}{l}\text { Granulin-5 - } \\
\quad \text { linker } 6\end{array}$ & $\begin{array}{l}\text { MWTLVSWVALTAGLVAGSAWSHPQFEKGGGSGGGSGGSAWSHPQFEKGASDYKDDDDKDVPCDNVSSCPSSDTCC } \\
\text { QLTSGEWGCCPIPEAVCCSDHQHCCPQGYTCVAEGQCQR }\end{array}$ \\
\hline $\begin{array}{l}\text { Granulin-6 - } \\
\quad \text { linker } 7\end{array}$ & $\begin{array}{l}\text { MWTLVSWVALTAGLVAGSAWSHPQFEKGGGSGGGSGGSAWSHPQFEKGASDYKDDDDKDIGCDQHTSCPVGQTCC } \\
\text { PSLGGSWACCQLPHAVCCEDRQHCCPAGYTCNVKARSCEK }\end{array}$ \\
\hline $\begin{array}{l}\text { Granulin-7 - } \\
\quad \text { linker } 8\end{array}$ & $\begin{array}{l}\text { MWTLVSWVALTAGLVAGSAWSHPQFEKGGGSGGGSGGSAWSHPQFEKGASDYKDDDDKDVECGEGHFCHDNQTCC } \\
\text { RDNRQGWACCPYRQGVCCADRRHCCPAGFRCAARGTKCLR }\end{array}$ \\
\hline
\end{tabular}

Each construct contains the human PGRN signal peptide followed by a twin-strep/FLAG tag (italicized) before the GRN \pm linker domains.

according to the manufacturer's protocol. Cells were harvested for biochemical analysis or fixed and immunostained after 24 or $48 \mathrm{~h}$. The TMEM106B constructs (AAV1 backbone; untagged or with C-terminal V5 tag) have been previously described (Nicholson et al., 2013). HeLa or HAP1 PGRN KO cells were plated in six-well plates and transfected with $2 \mu \mathrm{g}$ of empty vector or TMEM106B for a total of $48 \mathrm{~h}$. For the PGRN KO cells, 24 $\mathrm{h}$ after transfection, mCherry-PGRN $(5 \mu \mathrm{g} / \mathrm{ml})$ was added to the media for an additional $24 \mathrm{~h}$ before lysing the cells for SDS-PAGE and immunoblot analysis.

\section{Cell lysis and immunoblotting}

For whole cell lysates, cells were washed $2 \times$ in PBS and lysed in ice-cold RIPA buffer (50 mM Tris-HCl, $\mathrm{pH} 8.0$, $150 \mathrm{mM} \mathrm{NaCl}, 1 \%$ Triton $\mathrm{X}-100,0.1 \%$ SDS, and $0.5 \%$ sodium deoxycholate) in the presence of protease and phosphatase inhibitors (catalog 78440; Pierce/Thermo Fisher). RIPA lysates were sonicated at $20 \%$ amplitude for 5 cycles of $2 \mathrm{~s}$ on/2 s off on ice using a sonic dismembrator (QSonica, LLC). Alternatively, a postnuclear lysate was obtained by lysing fresh cell pellets in $50 \mathrm{mM}$ Tris, $\mathrm{pH}$ 8.0, $150 \mathrm{mM} \mathrm{NaCl}, 0.5 \%$ Triton $\mathrm{X}-100$ on ice for $15 \mathrm{~min}$ followed by centrifugation at $14,000 \mathrm{rpm}$ for $10 \mathrm{~min}$ at $4^{\circ} \mathrm{C}$. Total protein was measured by BCA assay (catalog 23222; Pierce/Thermo Fisher) and reduced immunoblot samples were prepared with $4 \times$ sample buffer $(125 \mathrm{mM}$ Tris, $\mathrm{pH} 6.8,8 \%$ LDS, $40 \%$ glycerol, Orange G) and 50 $\mathrm{mM}$ tris(2-carboxyethyl)phosphine (TCEP) followed by heat-denaturing at $70^{\circ} \mathrm{C}$ for $15 \mathrm{~min}$. TCEP was omitted for nonreduced samples. Typically, samples of equal protein were run on a range of Bio-Rad TGX minigels and transferred to $0.2 \mu \mathrm{m}$ nitrocellulose membranes using the BioRad Trans-blot Turbo system. Membranes were blocked with LiCor Odyssey blocking buffer for $1 \mathrm{~h}$ at room temperature followed by incubation with primary antibody (diluted in 1:1 TBST/blocking buffer) overnight at $4^{\circ} \mathrm{C}$ with gentle rocking. HRP-conjugated secondary antibodies (The Jackson Laboratory or Cell Signaling Technologies, CST) diluted in 5\% milk/TBST or LiCor fluorescent secondaries diluted in 1:1 TBST/blocking buffer were used. West Dura or West Femto (Pierce) substrate was used for chemiluminescent detection. Blots were imaged using an Odyssey Fc (LiCor) and analyzed using Image Studio software (version 3.1) for densitometry analysis. Detailed information about the anti-PGRN primary antibodies used in this study can be found in Table 3. The following additional primary antibodies were used for immunoblot: neurotensin III/sortilin (1:1000; BD Biosciences, catalog 612101, RRID:AB_399472), LAMP1 (1:5000; CST, catalog 9091), cathepsin D (1:1000; Santa Cruz Biotechnology, catalog sc-6486, RRID:AB_637896), Rab5 (1:1000; CST, 
Table 3. List of anti-PGRN primary antibodies used in this study

\begin{tabular}{|c|c|c|c|c|c|c|c|}
\hline Vendor & Catalog number/(RRID) & Species & Clonality & Immunogen & $\begin{array}{l}\text { Antibody } \\
\text { stock }\end{array}$ & $\begin{array}{l}\text { Immunoblot } \\
\text { dilution }\end{array}$ & $\begin{array}{l}\text { ICC } \\
\text { dilution }\end{array}$ \\
\hline R\&D Systems & AF2420/(2114489) & Goat & Poly & aa $18-593$ & $1 \mu \mathrm{g} / \mu \mathrm{l}$ & $1: 500-1: 1000$ & $1: 500$ \\
\hline R\&D Systems & MAB2420/(2114488) & Mouse & Mono & aa $18-593$ & $1 \mu \mathrm{g} / \mu \mathrm{l}$ & $1: 500-1: 1000$ & $1: 300$ \\
\hline Sigma (Atlas) & HPA008763/(1234492) & Rabbit & Poly & aa $128-271$ & $0.1 \mu \mathrm{g} / \mu \mathrm{l}$ & $1: 500-1: 1000$ & $1: 250$ \\
\hline Life Technologies & $40-3400 /(2533461)$ & Rabbit & Poly & C-terminal protein & $0.25 \mu \mathrm{g} / \mu \mathrm{l}$ & $1: 500-1: 1000$ & $1: 50$ \\
\hline Novus/SDIX & $26320002 /(2114484)$ & Rabbit & Poly & aa $289-426$ & $0.5 \mu \mathrm{g} / \mu \mathrm{l}$ & $1: 500$ & $1: 250$ \\
\hline Abcam/Epitomics & ab108608/EPR3781/(10888818) & Rabbit & Mono & Synthetic protein & $0.5 \mu \mathrm{g} / \mu \mathrm{l}$ & $1: 500$ & N/A \\
\hline ENZO & ALX-804-737-C100/(2052325) & Mouse & Mono & Human PGRN & $1 \mu \mathrm{g} / \mu \mathrm{l}$ & $1: 1000$ & $\mathrm{~N} / \mathrm{A}$ \\
\hline Santa Cruz & (C-11) sc-377036/(Not listed) & Mouse & Mono & aa $21-320$ & $0.2 \mu \mathrm{g} / \mu \mathrm{l}$ & $1: 250$ & $1: 50$ \\
\hline GenScript & Linker-3 (custom)/(n/a) & Rabbit & Poly & $\begin{array}{l}\text { aa } 187-200 \\
\text { LAKKLPAQRTNRAVC }\end{array}$ & $0.18 \mu \mathrm{g} / \mu \mathrm{l}$ & $1: 10,000$ & $\mathrm{~N} / \mathrm{A}$ \\
\hline Custom & 4C1 (custom)/(n/a) & Mouse & Mono & Human C-TAP PGRN & Unknown & $1: 50$ & $\mathrm{~N} / \mathrm{A}$ \\
\hline LS BIO & LS-C154960/(Not listed) & Goat & Poly & aa $248-259$ & $0.5 \mu \mathrm{g} / \mu \mathrm{l}$ & $1: 500$ & $1: 50$ \\
\hline Adipogen & AG-25A-0090-C100/(249045) & Rabbit & Poly & Human GRN C & $1 \mu \mathrm{g} / \mu \mathrm{l}$ & 1:1000 & $1: 250$ \\
\hline
\end{tabular}

aa $=$ amino acid, ICC = immunocytochemistry

catalog 2143, RRID:AB_823625), RCAS1 (1:1000; CST, catalog 12290, RRID:), calnexin (1:1000; CST, catalog 2433, RRID:AB_2243887), COXIV (1:1000; CST, catalog 4850, RRID:AB_2085424), TMEM106B (1:10,000; Pierce/ Thermo Fisher, catalog PA5-34353, RRID:AB_2551705), StrepMAB-Immo (1:10,000; IBA, catalog 2-1517-001, RID:AB_513134), or V5 (1:1000; Life Technologies, catalog R960-25, RRID:AB_2556564). Actin (1:10,000; Abcam/ Epitomics, catalog ab8227, RRID:AB_2305186), GAPDH (1: 5000; Sigma, catalog G8795, RRID:AB_1078991), or tubulin (1:20,000; Abcam/Epitomics, catalog 1878-1, RRID: AB_765089) were used as loading controls.

\section{Tissue lysis and immunoblotting}

Frozen brain tissue from human control (three males and two females) and FTD-GRN (two males and three females) cases (Table 4) or mice (of either sex) was first ground under liquid nitrogen to create a uniform powder. Human brain tissue was obtained from Brodmann area 9 of the frontal cortex, an area commonly affected in FTD. Control brains were cognitively normal at autopsy and did not have neuropathological features for major markers of neurodegenerative pathologies including $\mathrm{A} \beta$, tau, $\alpha$-synuclein, ubiquitin, p62, or TDP-43. FTD-GRN cases were classified based on DNA sequencing to harbor a known pathogenic GRN mutation and to have neuropathology consistent with a diagnosis of FLTD using standard measures including staining for p62, ubiquitin, and p-TDP43 (Mackenzie and Neumann, 2017). Roughly equal weights of frozen powder were extracted with the cytoplasmic extraction buffer (CEB) from the Pierce Subcellular Fractionation kit using a Dounce homogenizer according to the manufacturer's protocol. Homogenates were centrifuged at $500 \times g$ for $10 \mathrm{~min}$ and the supernatant was saved for total protein analysis (BCA) and SDS-PAGE or ELISA (see below). The remaining pellets were further extracted in $8 \mathrm{M}$ urea to obtain an insoluble protein fraction. For SDS-PAGE, $50 \mu \mathrm{g}$ of protein was separated on 12 well, $12 \%$ Bis-Tris gels (Bio-Rad or Genscript) and transferred to $0.2 \mu \mathrm{m}$ nitrocellulose membranes in MES buffer followed by immunoblotting as described above. to detect mature GRNs, the membrane was cut at $\sim 15 \mathrm{kDa}$, and the bottom was incubated separately with GRN-detecting antibodies to avoid visu-

Table 4. Case details of human subjects. PMI = postmortem interval

\begin{tabular}{|c|c|c|c|c|}
\hline Primary neuropathologic diagnosis & Sex & Age at death (years) & PMI (h) & Disease duration (years) \\
\hline Control & $\mathrm{F}$ & 60 & 8 & - \\
\hline Control & $\mathrm{F}$ & 57 & 17 & - \\
\hline Control & $M$ & 59 & 6 & - \\
\hline Control & M & 65 & - & - \\
\hline Control & M & 70 & 4.5 & - \\
\hline FTD-GRN & $\mathrm{M}$ & 63 & - & 5 \\
\hline FTD-GRN & M & 71 & 15.5 & 4.5 \\
\hline FTD-GRN & $\mathrm{F}$ & 61 & 6 & 6 \\
\hline FTD-GRN & $\mathrm{F}$ & 61 & 7 & 6 \\
\hline FTD-GRN & $\mathrm{F}$ & 62 & 11.5 & 10 \\
\hline Group & Sex (M/F) & Mean \pm SEM & Mean \pm SEM & Mean \pm SEM \\
\hline Control & $5(3 / 2)$ & $62.2 \pm 2.36$ & $8.9 \pm 2.80$ & - \\
\hline FTD-GRN & $5(2 / 3)$ & $63.6 \pm 1.89$ & $10.0 \pm 2.19$ & $6.3 \pm 0.97$ \\
\hline
\end{tabular}


alization of nonspecific protein bands that migrate at higher MWs.

\section{Protein deglycosylation}

Samples of postnuclear lysates from HEK293T cells expressing GRN(+linker) constructs were incubated overnight at $37^{\circ} \mathrm{C}$ with native PNGase $\mathrm{F}$ (New England Biolabs; catalog P0704S) or mock treatment according to the manufacturer's instructions.

\section{Secreted PGRN and GRN measurements}

HEK-PGRN cells were plated in 6-cm dishes in complete DMEM media (with serum). When the cells were $\sim 80 \%$ confluent, the media were removed, the cells were washed $2 \times$ with PBS, and serum-free Opti-MEM media (Life Technologies) was added. After $24 \mathrm{~h}$, the media were removed and immediately centrifuged at $6000 \mathrm{rpm}$ for 5 min to remove any cell debris. The supernatants were directly applied to a 3-kDa MW cutoff spin filter and centrifuged to obtain a $10 \times$ concentrated sample (500-50 $\mu \mathrm{l}$ in an Amicon Ultra; Millipore) or $30 \times$ concentrated sample (5 $\mathrm{ml}$ to $\sim 160 \mu \mathrm{l}$ in a Vivaspin 6; GE Healthcare). The resulting concentrates were collected and mixed with $4 \times$ sample buffer as above. A total of $20 \mu$ l of each media sample was loaded onto a gel for SDS-PAGE followed by transfer to nitrocellulose membranes for total protein stain (REVERT; LiCor) or immunoblot analysis.

\section{PGRN pulse-chase assay}

HAP1 PGRN KO cells were plated in a 12-well dish. The following day, the cells were treated (pulse) with recombinant PGRN diluted in the media for $24 \mathrm{~h}$ as indicated. After the 24-h pulse, the media were removed, cells were washed $2 \times$ with PBS, and fresh media without recombinant PGRN was applied (chase). Cells were harvested at the indicated time points for immunoblot or immunocytochemistry.

\section{Lysosome density gradient centrifugation}

Approximately $200 \mathrm{mg}$ of fresh HeLa cells were fractionated using the Lysosome Enrichment kit for Tissue and Cultured Cells (Thermo Scientific/Pierce \#89839) according to the manufacturer's protocol. Briefly, the cells were vortexed in $800 \mu \mathrm{l}$ of enrichment buffer A for $5 \mathrm{~s}$ followed by incubation on ice for $2 \mathrm{~min}$. The cell suspension was then transferred to a Dounce homogenizer and homogenized on ice using 70-80 strokes. Next, the lysate was transferred to a 2-ml tube and $800 \mu$ l of enrichment buffer $B$ was added. The lysate was inverted several times to mix. The lysate was then centrifuged at $500 \times g$ for 10 $\min$ at $4^{\circ} \mathrm{C}$ and the supernatant was collected and transferred to a new tube on ice until needed. Next, in an ultracentrifuge tube, a discontinuous density gradient was prepared by carefully overlaying the prepared OptiPrep Gradients in descending concentrations as follows: $30 \%$, $27 \%, 23 \%, 20 \%$, and $17 \%$. The prepared cell extract was mixed with the OptiPrep Cell Separation Media to make a final concentration of 15\% OptiPrep Media (1500 $\mu$ l extract $+500 \mu$ l OptiPrep). The 15\% OptiPrep sample was then overlaid on top of the gradient and centrifuged at $33,000 \mathrm{rpm}$ for $2 \mathrm{~h}$ at $4^{\circ} \mathrm{C}$ in a Beckman Ti41 swinging- bucket rotor. After centrifugation, $500 \mu \mathrm{l}$ aliquots of the gradient were carefully removed (12 fractions total) from the top down and used for immunoblot analysis of organelle separation. The top $2 \mathrm{ml}$ of the centrifuged gradient (fractions 1-4) contained the enriched lysosomes.

\section{Fluorescent immunolabeleing of cells and tissue}

HeLa or HAP1 cells were fixed with $4 \%$ paraformaldehyde for $30 \mathrm{~min}$ at room temperature. Cells were then permeabilized and blocked with $3 \%$ BSA $+0.05 \%$ saponin in PBS for $1 \mathrm{~h}$ at room temperature. Next, primary antibodies were diluted in blocking buffer and incubated overnight at $4^{\circ} \mathrm{C}$. Alternatively, some cells were fixed with 4\% PFA for $15 \mathrm{~min}$ at room temperature followed by permeabilization with ice-cold methanol for $10 \mathrm{~min}$. After blocking with $0.1 \%$ BSA in PBS, cells were incubated with primary antibodies overnight at $4^{\circ} \mathrm{C}$ in blocking buffer. PGRN primary antibodies and their concentrations used are listed in Table 3. Additional primary antibodies used are as follows: LAMP1 (CST; 1:2000), Rab5 (CST; 1:200), RCAS1 (CST; 1:200), calnexin (CST; 1:50), and COXIV (CST; 1:250). After washing with PBS, cells were incubated in secondary antibodies conjugated to Cy5 (1:500; Jackson ImmunoResearch) and/or Alexa Fluor 488 (1:500; Life Technologies) for $1 \mathrm{~h}$ at room temperature. Slides were mounted using ProLong Gold Antifade Reagent with DAPI (Life Technologies). For immunolabeling of mouse brains, $30 \mu \mathrm{m}$ free-floating sections were used. Briefly, brains were harvested and drop-fixed in 4\% PFA for $2 \mathrm{~d}$, and then transferred to $30 \%$ sucrose until saturation. Sectioning was performed on a freezing sliding microtome and free-floating sections stored in cryoprotectant solution. For immunostaining, sections were thoroughly washed in PBS and blocked for $1 \mathrm{~h}$ in $5 \%$ normal goat serum in PBS, with $0.5 \%$ Triton X-100 for permeabilization. Sections were then incubated with the following primary antibodies diluted in blocking solution overnight at $4^{\circ} \mathrm{C}$ : V5 (Life Technologies, 1:1000) and NeuN (EMD Millipore; 1:500). After washing in PBS, sections were incubated with secondary antibodies conjugated to Cy-3 (Jackson ImmunoResearch; 1:500) and Alexa Fluor 488 (Life Technologies, 1:500) diluted in blocking solution with addition of DAPI (Life Technologies, 1:1000) for $1 \mathrm{~h}$ at room temperature. Finally, sections were washed in PBS and mounted using Vectashield Hard Set (Vector Laboratories). Images were captured at room temperature with an EVOS FL Cell Imaging System (20× objective; Life Technologies) and postprocessed in Adobe PhotoShop CS5. For Super Resolution Microscopy, images (z-stack images encompassing GRN and LAMP1 signal, typically 30-40 planes, 125-nm step size) were taken at room temperature using a GE Delta Vision OMX Blaze with 3D Structure Illumination Microscopy (SIM; 60× NA 1.42 objective; GE Healthcare Life Sciences). Raw structured illumination data were reconstructed using DeltaVision's SoftWorx application, and the resulting high resolution z-stacks were visualized and processed using Fiji and Imaris v8.2 software (Bitplane). 


\section{PGRN ELISA}

Human Progranulin DuoSet ELISA reagents were from R\&D Systems and the ELISA was conducted according to the manufacturer's protocol. Cell culture media samples were pre-cleared of cell debris by spinning for $5 \mathrm{~min}$ at $6000 \mathrm{rpm}$ at $4^{\circ} \mathrm{C}$ and diluted $1: 4$ or $1: 5$ in $1 \times$ Reagent Diluent \#2. Brain lysates were diluted 1:5 in $1 \times$ Reagent Diluent \#2. All ELISA measurements were done in duplicate and fell within the standard curve generated by the provided recombinant PGRN standard. PGRN measurements were normalized to the total protein in the lysate and compared to the indicated control.

\section{Cathepsin L studies}

Recombinant human cathepsin $L$ was from R\&D Systems (\#952-CY). For in vitro cleavage assays, recombinant cathepsin $L$ was incubated with recombinant human C-TAP PGRN at a ratio of 1:10 (enzyme:substrate, typically 200:2000 $\mathrm{ng}$ ) in assay buffer [50 mM MES, $5 \mathrm{mM}$ DTT, $1 \mathrm{mM}$ EDTA, $0.005 \%$ (w/v) Brij-35, pH 6.0] at $37^{\circ} \mathrm{C}$ for the indicated times. At each time point, an aliquot of the mixture was removed and mixed with $4 \times$ sample buffer for immunoblot analysis. For cell culture inhibitor studies, HAP1 wild-type (WT) cells were plated in 12-well plates. The following day, the cells were treated with the cathepsin L inhibitor II (Z-FY-CHO; Calbiochem) in the media at the concentrations indicated. HAP1 WT cells were harvested after $40 \mathrm{~h}$ for immunoblot analysis. Cells were lysed and analyzed by immunoblot as described above.

\section{Human adeno-associated virus serotype 2/1 (AAV2/ 1)/1-PGRN injections}

All animal procedures were performed in accordance with the Emory University animal care committee's regulations. We performed somatic brain transgenesis (SBT) to overexpress eGFP or human N-TAP PGRN in Grn KO mice of either sex. Briefly, recombinant AAV2/1 encoding eGFP or human $\mathrm{N}$-TAP PGRN were generated and neonatal PO injections of rAAV2/1 were performed (Chakrabarty et al., 2013).

\section{Results}

\section{Expression of recombinant GRN proteins and identification of antibodies that detect GRNs}

The lack of tools to study endogenous GRNs has limited the field's ability to study the normal functions of PGRN and to determine how loss of PGRN leads to lysosome dysfunction and neurodegeneration. To overcome this gap, we developed a system to selectively express each human GRN in mammalian cells. This system enabled us to screen anti-human PGRN antibodies by immunoblot to determine which region(s) of PGRN they detect. First, we generated expression constructs for each of the human GRN proteins: para-GRN, GRN-1, GRN-2, GRN-3, GRN-4, GRN-5, GRN-6, and GRN-7, with $(+)$ and without $(-)$ their endogenous $C$-terminal linker regions (Fig. 1A; Table 2; Materials and Methods). At the $\mathrm{N}$ terminus, each GRN construct was engineered to contain the authentic PGRN signal peptide to ensure proper routing into the secretory pathway, followed by twin-Strep tags and a FLAG tag, to facilitate purification and detection. Next, we transfected the GRN constructs into HEK293T cells and were able to detect all of the expressed GRN proteins in cell lysates and conditioned media, indicating GRNs are properly synthesized and secreted (Fig. 1B,C). Some GRNs migrated as multiple bands, suggesting post-translational glycosylation. To confirm this, we incubated GRN(+linker) overexpressing cell lysates with or without PNGase F and detected proteins by immunoblot (Fig. 1D). We found that several GRNs or linker regions, including GRN-1(+L2), GRN$3(+\mathrm{L} 4)$, and GRN-7(+L8), collapsed to a single band after PNGase treatment, indicating these regions are glycosylated, consistent with published $\mathrm{N}$-linked glycosylation sites (Songsrirote et al., 2010). Next, we used our expression system to screen a panel of commercial and in-house polyclonal and monoclonal antibodies developed against recombinant full-length PGRN or peptides using immunoblot (Table 3). Under reducing conditions, we found that many of the PGRN antibodies detect a single linker region of PGRN, suggesting that these unstructured regions of PGRN may be immuno-dominant epitopes (Fig. 1E). Encouragingly, we also identified multiple antibodies that detect one or more specific GRNs (Fig. 1F). These included the AF2420 (R\&D Systems) polyclonal antibody, which detects GRN-1, GRN-2 (weakly), and GRN-3 and antibodies that detect GRN-2 (Sigma, Santa Cruz C-11), GRN-3 (LS Bio, Sigma weakly), GRN-4 (Novus), and GRN-5 (Adipogen). Notably, the AF2420 antibody detects nearly all linker regions of PGRN, in addition to multiple GRNs, making it a potentially useful tool for dissecting intermediate PGRN cleavage products in combination with other linker-specific antibodies.

\section{Endogenous, intracellular GRNs are present in various cell types}

Next, we determined if any of the PGRN antibodies could detect endogenous GRNs in cell lysates by immunoblot. To test antibody specificity, we knocked out GRN in a near-haploid human cell line (Essletzbichler et al., 2014) using CRISPR-Cas9 to generate the HAP1 PGRN $\mathrm{KO}$ cell line. Then, we compared antibody reactivity in whole-cell lysates from HAP1 WT and PGRN KO lines. Most antibodies detected endogenous, full-length PGRN in HAP1 WT lysates at the expected MW of $\sim 75 \mathrm{kDa}$ (Fig. $2 A)$. In addition, we also observed multiple immunoreactive bands in the 15- to 75-kDa range that were present in both WT and PGRN KO cells, indicating they are nonspecific. This result highlights the importance of extensive antibody validation (Uhlen et al., 2016) and is especially important for PGRN, because nonspecific bands could be misinterpreted as PGRN cleavage products. Two antibodies (Sigma and Novus) detected specific bands at lower MWs $(<15 \mathrm{kDa})$ that correspond to the expected size of individual mature GRN proteins (Fig. 2A). Next, we screened the same panel of PGRN antibodies against immunoblots of whole-cell lysates from HEK293T cells stably overexpressing human PGRN (HEK-PGRN). Here, we identified multiple antibodies (R\&D AF2420, Sigma, Santa Cruz C-11, Novus) that detected specific bands at 
A

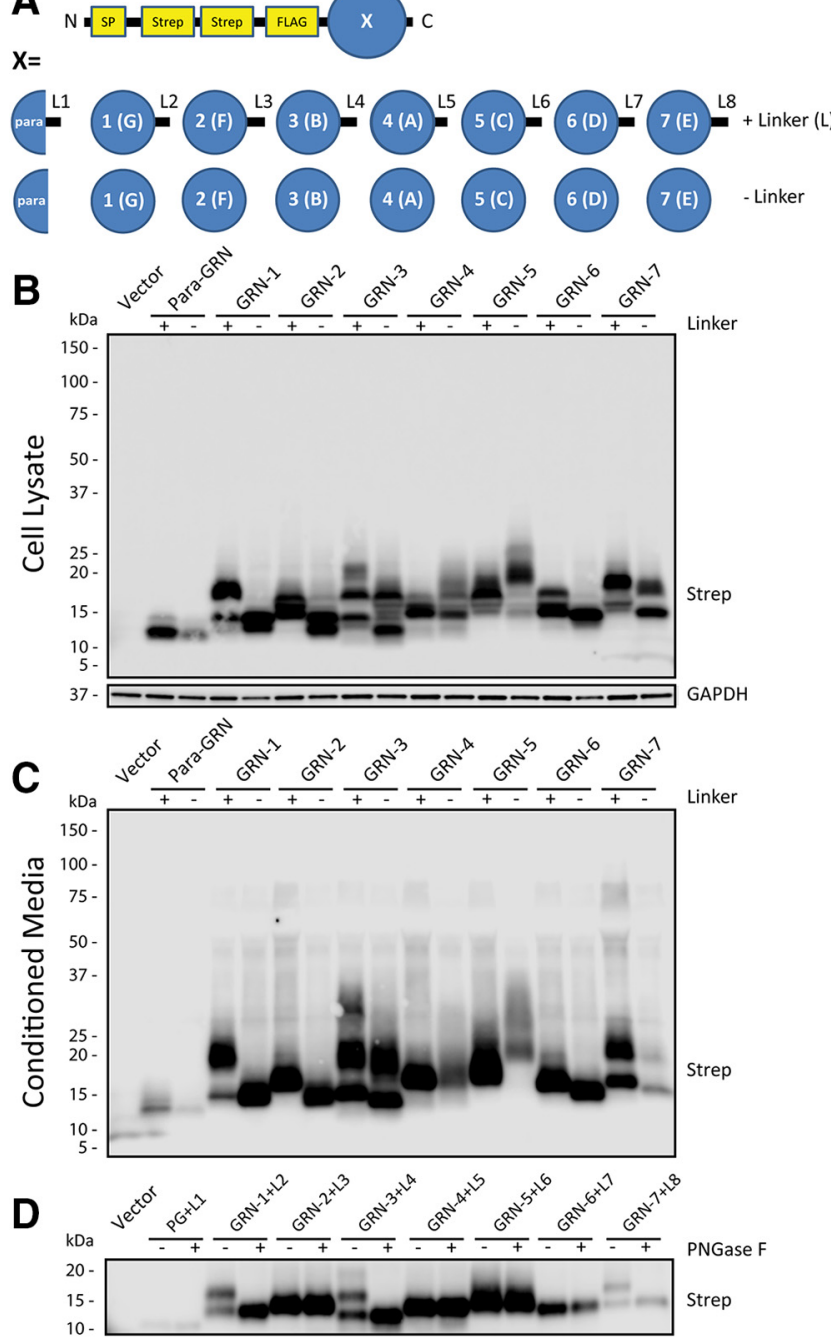

E

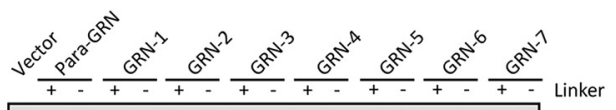

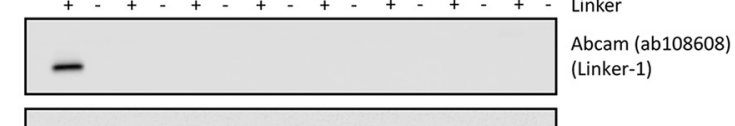
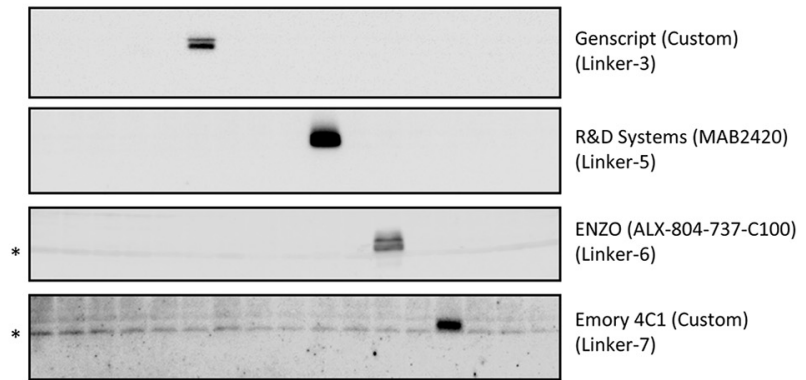
$\equiv \begin{aligned} & \text { Life Technologies (40-3400) } \\ & \text { (Linker-8) }\end{aligned}$
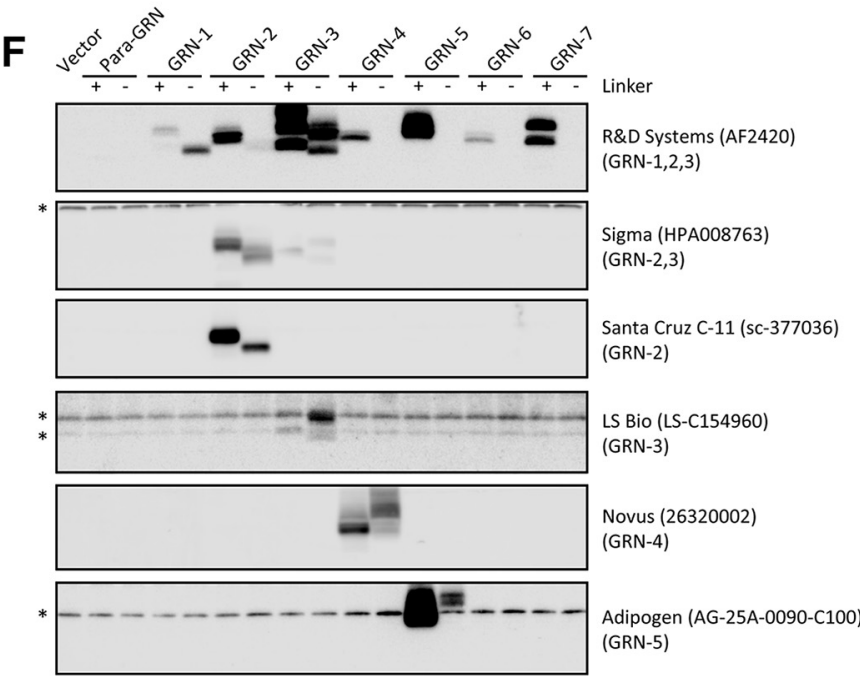

Figure 1. Expression of recombinant human GRNs and identification of antibodies that detect GRNs. $\boldsymbol{A}$, Schematic of human GRN expression constructs. Human GRN sequences (Table 2), with and without adjacent C-terminal linker regions, were synthesized to include the N-terminal PGRN signal peptide (SP), followed by twin-Strep (SAWSHPQFEK) tags and a single FLAG (DYKDDDDK) tag. Throughout the manuscript, individual GRNs are referred to by their numerical sequential designation (i.e., GRN-1, GRN-2, etc.), which correspond to their original alphabetical designation (i.e., GRN-G, GRN-F, etc.). B, C, HEK293T cells were transfected with the human GRN constructs and $48 \mathrm{~h}$ later either $(\boldsymbol{B})$ whole-cell lysates or $(\boldsymbol{C})$ conditioned media were analyzed by immunoblot for protein expression using the StrepMAB-immo antibody. $\boldsymbol{D}$, Cell lysates from GRN(+linker) overexpressing cells were mock (-) or PNGase $F$ $(+)$ treated to detect glycosylated proteins. $\boldsymbol{E}, \boldsymbol{F}$, GRN-expressing HEK293T cell lysates were analyzed by immunoblot to identify PGRN antibodies that either $(\boldsymbol{E})$ detect single linker regions of PGRN or (F) detect GRNs. The specific PGRN linker or GRN(s) detected are listed under each antibody. Detailed information about the PGRN antibodies screened can be found in Table 3. Asterisks (*) denote nonspecific protein bands.

the expected MWs for GRNs that were increased in the HEK-PGRN lysates compared to HEK-WT lysates (Fig. $2 B$ ). GRNs were only detected in the reduced samples (+TCEP), whereas full-length PGRN could often be detected in reduced or nonreduced samples. We did not detect any endogenous GRN bands $<15 \mathrm{kDa}$ in the HEKPGRN lysates using the antibodies specific for GRN-3 (LS Bio) or GRN-5 (Adipogen; Fig. 2B). Together, these data demonstrate that multiple GRN proteins, specifically GRN-2 and GRN-4, are endogenously present inside cells. Finally, we assessed the specificity of the PGRN antibodies using fluorescent immunocytochemistry in HAP1 WT and PGRN KO cells. We found that only the
R\&D MAB2420 and R\&D AF2420 antibodies were specific for PGRN/GRN immunolabeling in these cells (Fig. $2 C)$. The nonspecific staining of the other PGRN antibodies mirrors the nonspecificity that we observed by immunoblots in Figure $2 A, B$.

Based on our observations, the Sigma antibody was the most sensitive and reliable for detection of human GRN by immunoblot. This antibody strongly recognizes GRN-2, with weaker reactivity to GRN-3 (referred to as GRN-2,3; Fig. $1 F$, thus we cannot conclusively say whether it detects endogenous GRN-2, GRN-3, or both in cell lysates. Nevertheless, we used this antibody to further study endogenous GRN-2,3 expression and production. We found 
A

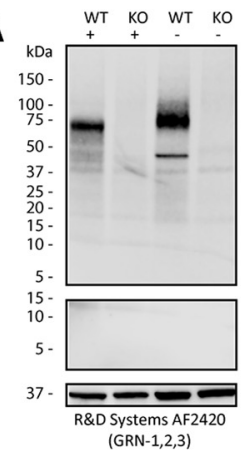

B
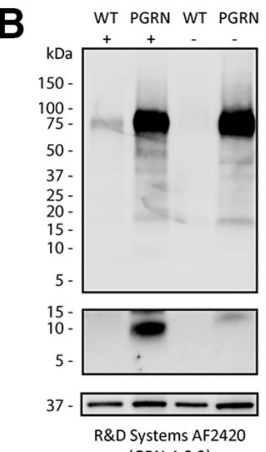

C (GRN-1,2,3)

KO

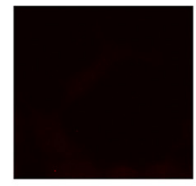

WT

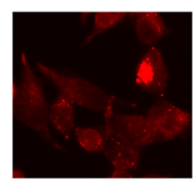

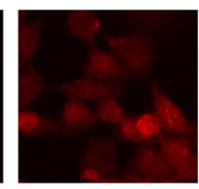

WT KO WT KO

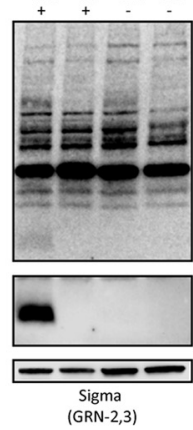

WT PGRN WT PGRN
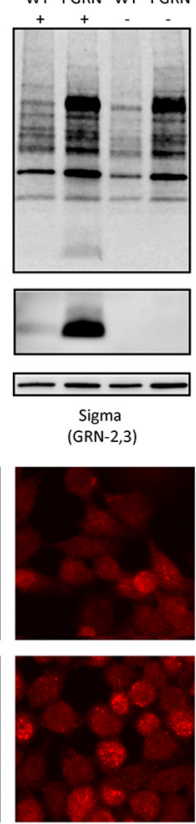

WT KO WT KO

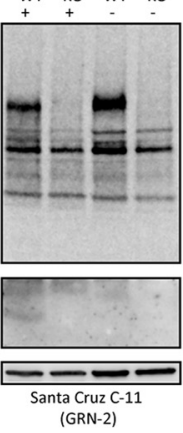

WT PGRN WT PGRN
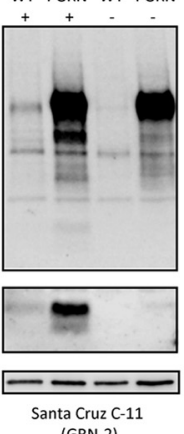

(GRN-2)
(anta Cruz C-11
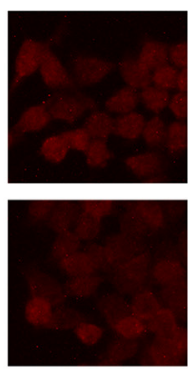

WT KO WT KO

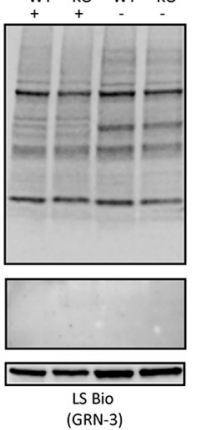

WT PGRN WT PGRN
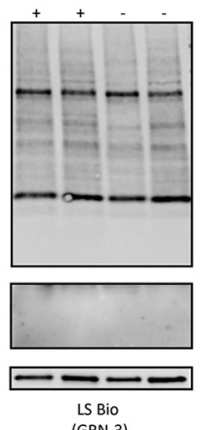

(GRN-3)
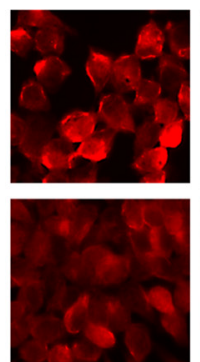

WT KO WT KO
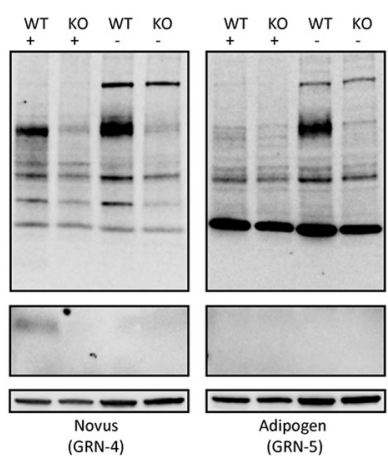

WT PGRN WT PGRN
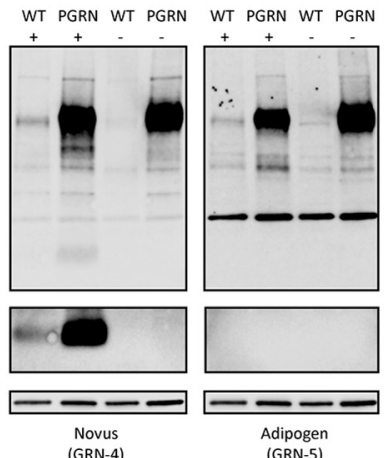

(GRN-4)
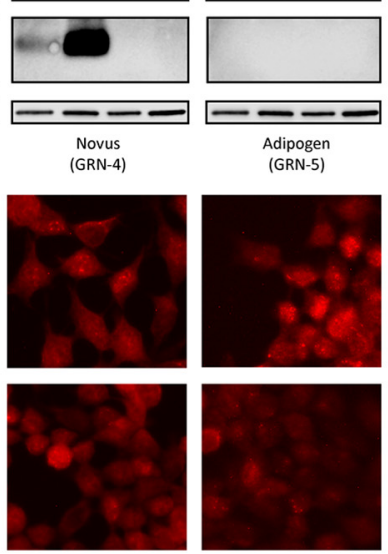

WT Kо WT KO
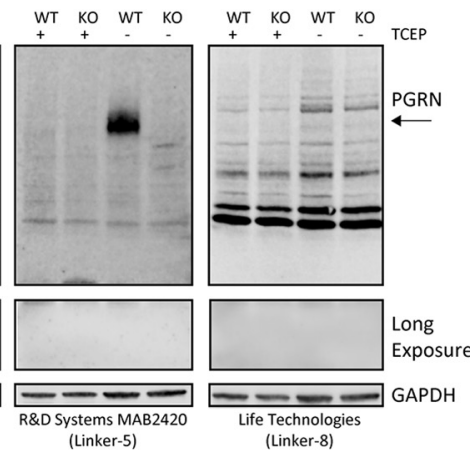

WT PGRN WT PGRN

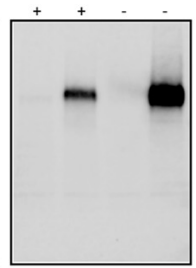

WT PGRN WT PGRN
$+\quad+\quad-\quad$ TCEP
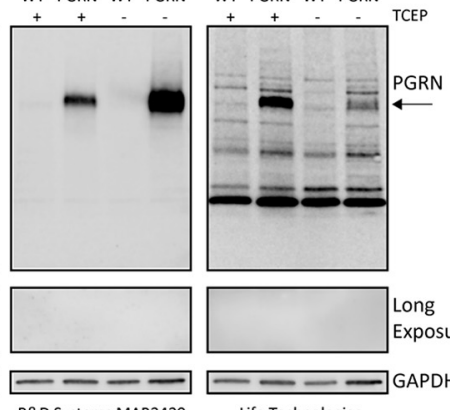

R\&D Systems MAB2420

(Linker-5)
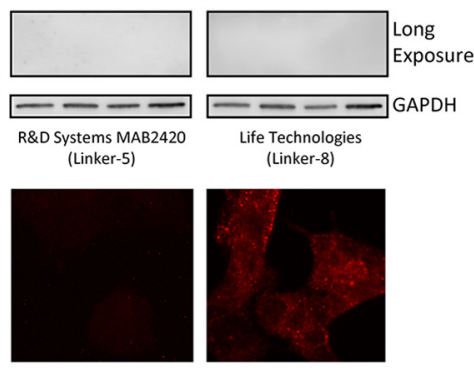

Life Technologies

(Linker-8)
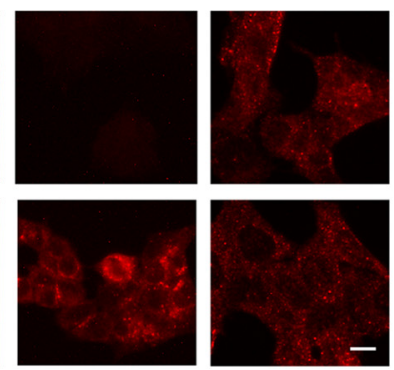

Figure 2. Specificity of PGRN antibodies and detection of multiple endogenous GRNs. $A$, Whole-cell lysates from HAP1 WT and HAP1 PGRN KO cells, either reduced (+TCEP) or nonreduced (-TCEP), were analyzed for PGRN antibody specificity by immunoblot. The bottoms of the blots $(<15 \mathrm{kDa})$ were exposed longer to reveal levels of endogenous GRNs. B, Whole-cell lysates from HEK293T WT and N-TAP PGRN stable overexpressing (PGRN) cells were analyzed as in A by immunoblot. $\boldsymbol{C}$, Representative immunofluorescent images of HAP1 PGRN KO and WT cells stained with the corresponding PGRN antibodies as in A and B. Scale bar, $10 \mu \mathrm{m}$.

that GRN-2,3 could be detected at steady-state levels in all human cell lines tested, notably with the highest levels in $\mathrm{H} 4$ (neuroglioma) and SH-SY5Y (neuroblastoma) cell lines (Fig. 3A). To determine if GRNs can be detected extracellular in the media of cultured cells, we grew HEKPGRN cells in serum-free media (Opti-MEM) for $24 \mathrm{~h}$, concentrated the media in a centrifugal spin filter $(3-\mathrm{kDa}$ MW cutoff), and analyzed the concentrate by total protein stain and immunoblot. As a control, we also concentrated Opti-MEM media alone. We detected a $\sim 5-\mathrm{kDa}$ protein band in both the conditioned media and media alone that increased in intensity with concentration (Fig. 3B). This protein is likely insulin (MW, $5.8 \mathrm{kDa}$ ), which is a principle component of Opti-MEM media, and confirmed that low MW proteins similar to GRNs in size were enriched in the concentrate. By immunoblot, we verified robust levels of secreted PGRN and cathepsin D, which served as a positive control for a secreted lysosomal protein, in the concentrated media. Conversely, GRNs (-2,3; Sigma and -4 ; Novus) were barely detectable, even in the $30 \times$ con- centrated media sample (Fig. $3 C$ ). These results indicate that these GRNs do not appear to be constitutively secreted or generated from secreted PGRN in cultured cells.

\section{GRNs are stable lysosomal proteins}

To monitor the production, stability, and localization of GRNs inside cells, we developed a PGRN pulse-chase assay based on the observation that application of purified extracellular PGRN was rapidly endocytosed by many cell lines. HAP1 GRN KO cells were treated (pulsed) with human mCherry-PGRN for $24 \mathrm{~h}$ and then chased with fresh media without PGRN for varying lengths of time. The levels of PGRN (R\&D AF2420), GRN-2,3 (Sigma), and GRN-4 (Novus) were measured at each time point by immunoblot. We found that after a $24 \mathrm{~h}$ pulse of mCherryPGRN, robust intracellular PGRN and GRN signals were observed by immunoblot (Fig. 4A). After a 6-h chase, the PGRN signal was virtually undetectable (Fig. $4 A, B$ ). Strikingly, a strong signal for GRN-2,3 and GRN-4 was still detected out to $16 \mathrm{~h}$ (Fig. $4 A, B$ ). These data indicate that 
A

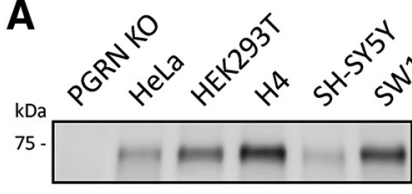

PGRN (AF2420)
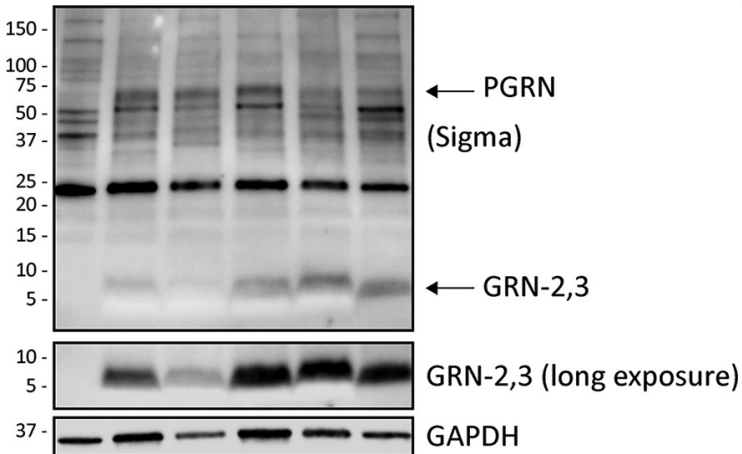

B

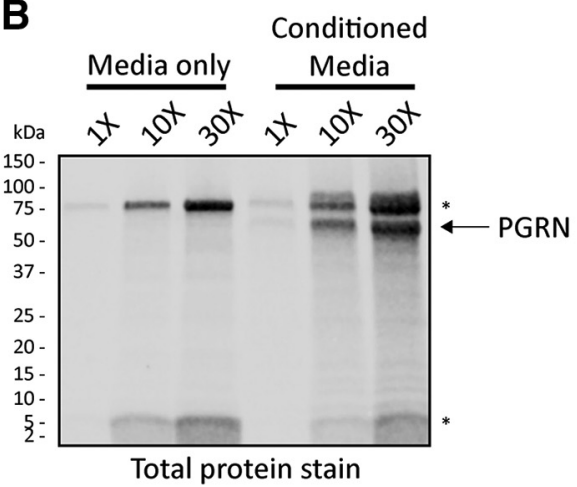

C

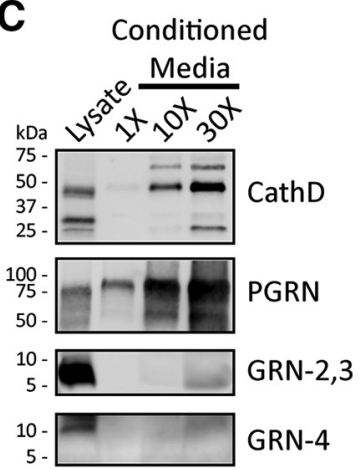

Figure 3. Endogenous GRNs are found intracellularly in a variety of cell types. $\boldsymbol{A}$, Whole-cell lysates (30 $\mu \mathrm{g}$ total protein) from commonly used cell types were analyzed for intracellular PGRN and GRN-2,3 by immunoblot. The entire Sigma immunoblot is shown to highlight the prominent nonspecific bands detected by the antibody (see PGRN KO lane). $\boldsymbol{B}$, Serum-free Opti-MEM media alone or conditioned media from HEK-PGRN cells grown for $24 \mathrm{~h}$ was concentrated, run on SDS-PAGE, and transferred to nitrocellulose membrane. Total proteins were visualized with REVERT total protein stain (LiCor) to ensure retention of low MW proteins. The bands designated with asterisks $(*)$ indicate proteins found in Opti-MEM media alone whereas the arrow points to secreted N-TAP PGRN. C, Concentrated serum-free conditioned media from HEK-PGRN cells was analyzed for secreted cathepsin D, PGRN (R\&D AF2420), and GRNs by immunoblot. All images are representative of at least two independent experiments.

endocytosed PGRN is rapidly processed into mature, stable GRNs. Similar results were obtained using purified N-TAP PGRN in the pulse-chase assay (data not shown). It is worth noting that we did not observe any accumulation of intermediate PGRN fragments in the $\sim 15$ - to 60 $\mathrm{kDa}$ range at any time point during the pulse-chase assay using the R\&D AF2420 antibody which detects multiple linker regions of PGRN (Fig. 4A).

Next, we immunostained PGRN KO cells pulse-chased with mCherry-PGRN (24-h pulse/6-h chase). Following a 6-h chase, the R\&D AF2420 antibody still gave a robust immunofluorescent signal (Fig. 4C). At this time point ( $t=$ 6 h) we only detect GRNs, not PGRN, by immunoblot (Fig. $4 A)$. As a control, we stained another set of cells with the R\&D MAB2420 antibody which is linker specific and only recognizes full-length PGRN. R\&D MAB2420 staining revealed punctate labeling after a $24 \mathrm{~h}$ pulse, but the signal was eliminated after the 6-h chase, indicating that fulllength, endocytosed PGRN had been metabolized. These results demonstrate that the R\&D AF2420 antibody can be used for immunofluorescent labeling of GRNs. To confirm this, we expressed every GRN(-linker) construct in PGRN KO cells for $24 \mathrm{~h}$ and immunostained them with the AF2420 antibody (Fig. 4E). Surprisingly, the antibody detected every expressed GRN protein. We then immunoblotted the GRN(-linker) overexpressed cell lysates from HEK293T cells under nonreducing conditions (-TCEP) and found that the AF2420 antibody now recognized nearly every GRN. These results indicate that the AF2420 polyclonal antibody may detect a conserved GRN motif under native-like conditions. In addition, the immunofluorescence data confirm processing of PGRN into stable GRNs and validate a useful tool for studying PGRN/GRN localization inside cells.
Extracellular or newly synthesized PGRN can be routed to the lysosome via multiple mechanisms (Hu et al., 2010; Zhou et al., 2015) where it colocalizes with the lysosomal marker, LAMP1. In HeLa cells, we observed significant overlap of LAMP1 and PGRN (R\&D AF2420) costaining (Fig. $5 A$ ), as has been previously reported (Chen-Plotkin et al., 2012). However, it has been unclear whether fulllength PGRN or GRNs are the main species localized to lysosomes. To address this, we used the validated antibodies that detect GRNs to explore the production and localization of GRNs inside cells. First, we performed density-based gradient centrifugation on HeLa lysates to determine where endogenous PGRN and GRN-2,3 fractionate based on organelle-specific proteins (Fig. $5 B$ ). PGRN was found throughout all of the fractions, which indicates its presence in the endoplasmic reticulum (ER), Golgi apparatus, and endosomes as previously reported (Ryan et al., 2009; Almeida et al., 2011; Capell et al., 2011). Alternatively, GRN-2,3 were exclusively concentrated in fractions that were most enriched for LAMP1, indicating their likely localization to lysosomes. Next, we assessed colocalization of GRNs with organelle markers in PGRN KO cells pulse-chased with PGRN (24-h pulse/ 6-h chase) using double-label immunofluorescence. Again, GRNs (as assessed by R\&D AF2420) showed significant colocalization with the lysosomal marker LAMP1 and did not overlap with markers for early endosomes (Rab5), the Golgi apparatus (RCAS1), the ER (calnexin), or mitochondria (COX IV; Fig. 5C). To analyze the localization of GRNs to lysosomes in more detail, we coupled our PGRN pulsechase assay with super-resolution microscopy (Fig. 5D). We found that GRNs were often associated with the inner leaflet of LAMP-1-positive vesicles that are likely lyso- 
A

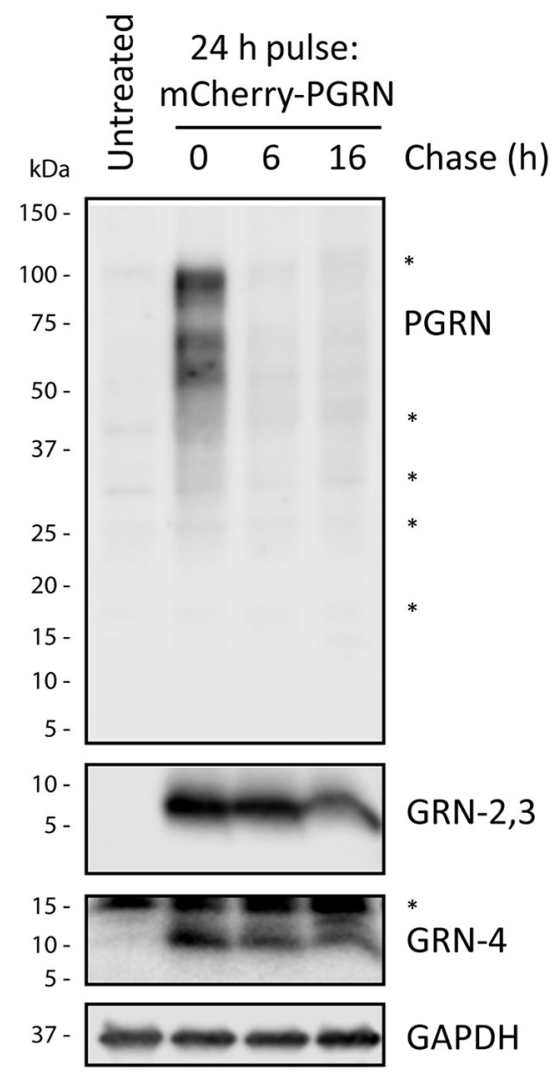

B

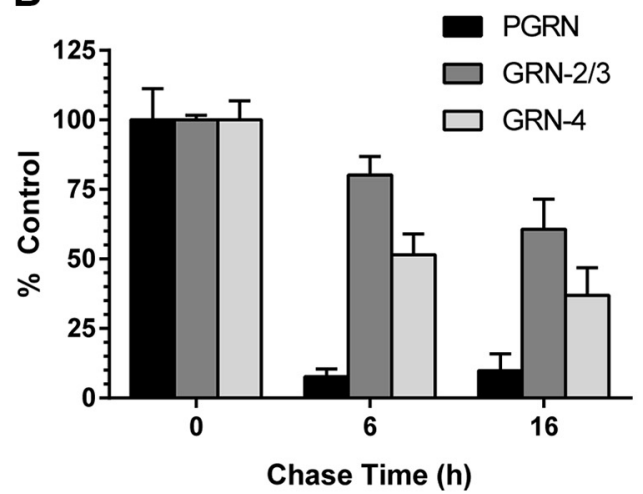

C

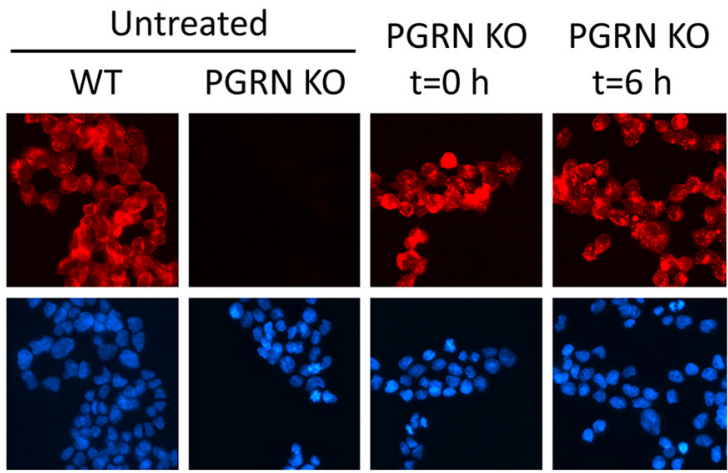

R\&D AF2420 / DAPI

D
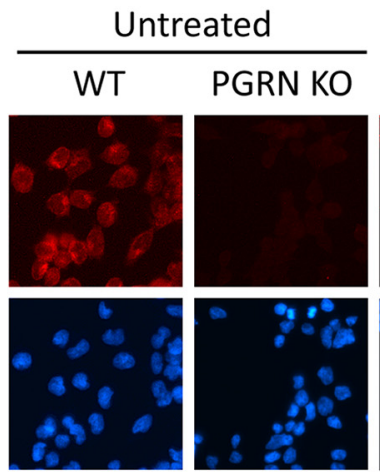

PGRN KO

PGRN KO

PGRN KO

$\mathrm{t}=0 \mathrm{~h}$

$\mathrm{t}=6 \mathrm{~h}$
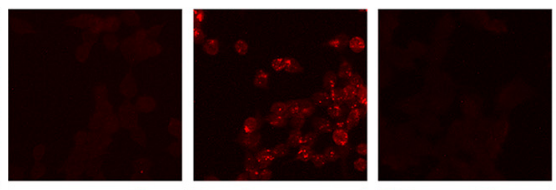

R\&D MAB2420 / DAPI

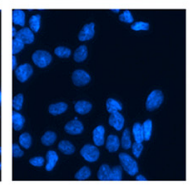

E

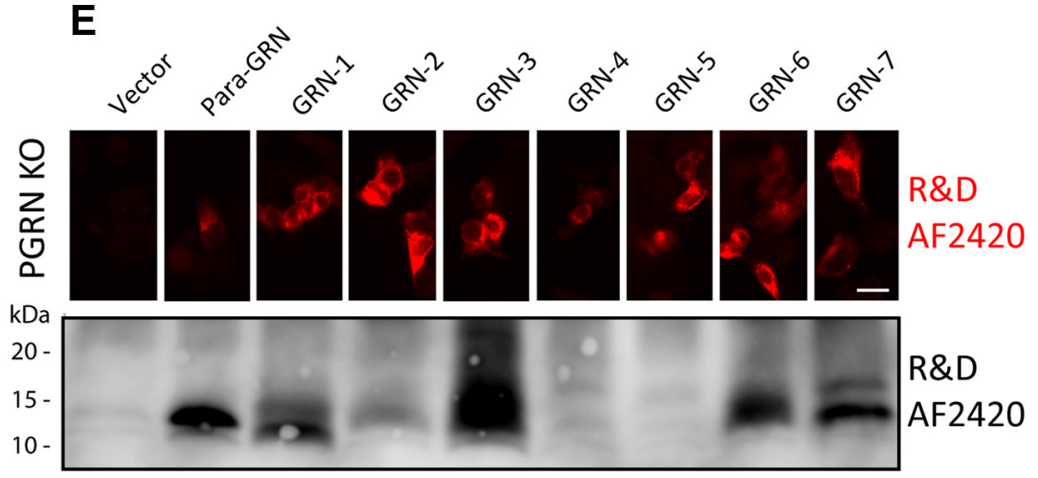

Figure 4. Endocytosed PGRN is rapidly processed into stable, mature GRNs. A, HAP1 PGRN KO cells were pulsed with mCherry-PGRN $(5 \mu \mathrm{g} / \mathrm{ml})$ in the media for $24 \mathrm{~h}$ and then chased with fresh media without PGRN for various lengths of time. Lysates were analyzed for PGRN (R\&D AF2420), GRN-2,3 (Sigma), and GRN-4 (Novus) by immunoblot. Equal volumes of lysates were run for each time point to account for differences in cell growth and measurements were normalized to untreated control (PGRN KO) background signal. Asterisks (*) denote nonspecific proteins. B, Quantification of PGRN and GRNs from A. Data represent mean \pm SEM of three independent replicates for each time point normalized to $t=0 \mathrm{~h}$ control. $\boldsymbol{C}, \boldsymbol{D}$, HAP1 PGRN KO cells pulsed with mCherry-PGRN $(5 \mu \mathrm{g} / \mathrm{ml})$ for $24 \mathrm{~h}(t=0 \mathrm{~h})$ and then chased with fresh media for $6 \mathrm{~h}(t=6 \mathrm{~h})$ were immunolabeled with either $(\boldsymbol{C})$ R\&D AF2420 (recognizes multiple PGRN linkers and GRNs) or (D) R\&D MAB2420 (recognizes only linker-5 of PGRN). Untreated HAP1 WT and PGRN KO cells are shown as specificity controls for antibody labeling. $\boldsymbol{E}$, top, HAP1 PGRN KO cells were transfected with GRN(-linker) constructs and immunolabeled with R\&D AF2420. Scale bar, $5 \mu \mathrm{m}$. Bottom, nonreduced (-TCEP) lysates from HEK293T cells transfected with GRN(-linker) constructs were immunoblotted with R\&D AF2420.

somes, suggesting that a portion of GRNs may be associated with the lysosome membrane and/or membranebound proteins (Fig. 5E). Taken together, these data demonstrate that GRNs, rather than PGRN, are the predominant stable species present in lysosomes.

\section{GRN levels are regulated by expression of SORT1 or TMEM106B}

PGRN levels have been linked to expression of several genes including SORT1, encoding the membrane receptor sortilin (Carrasquillo et al., 2010; Hu et al., 2010), and 
A
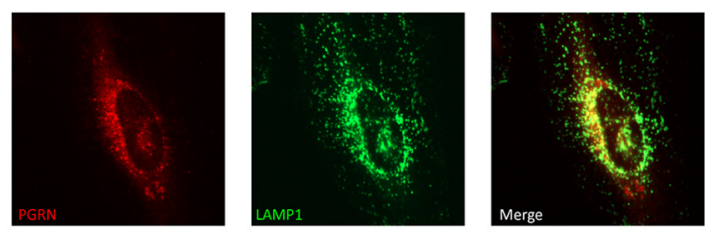

C
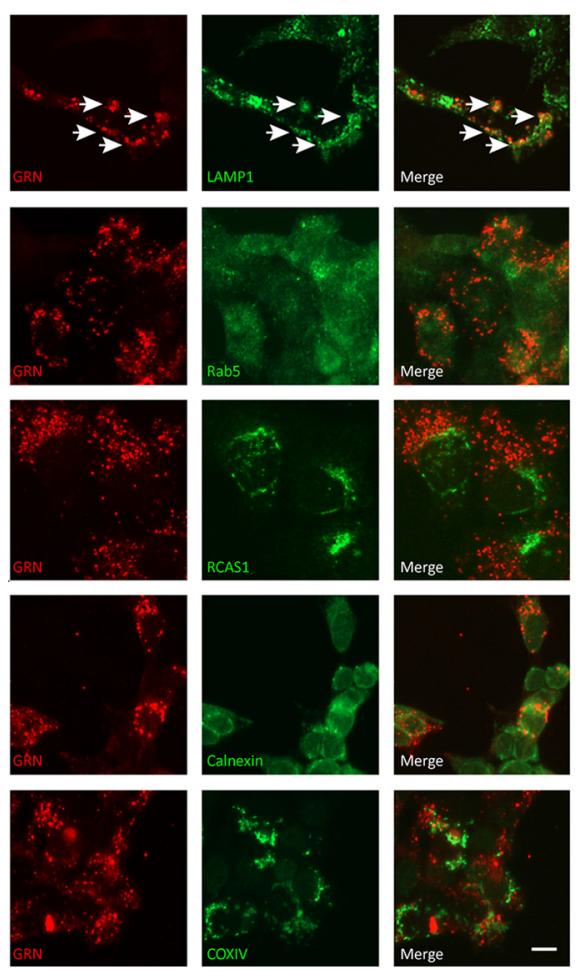
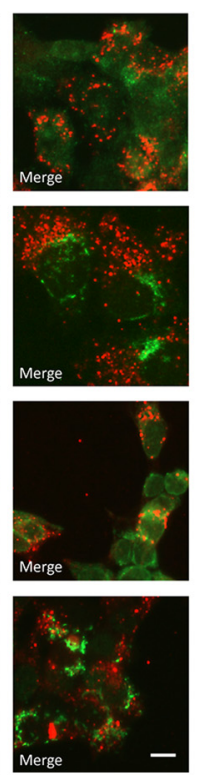

B

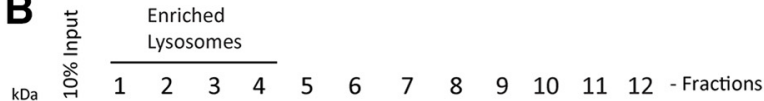

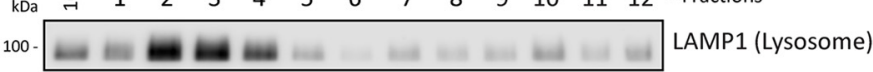
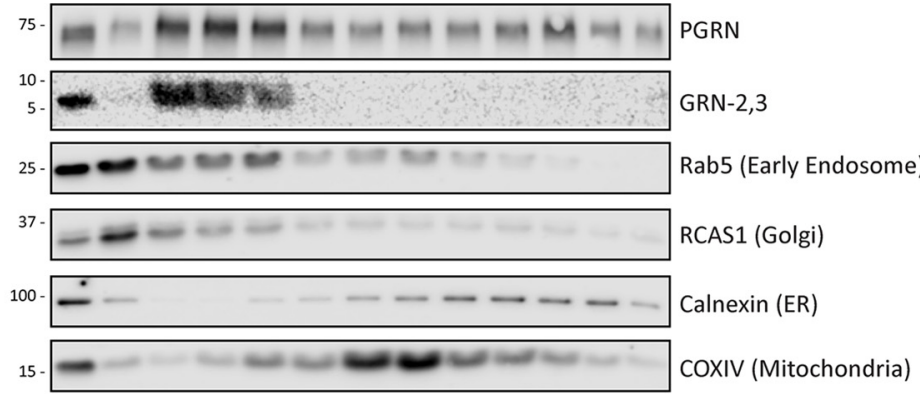

D

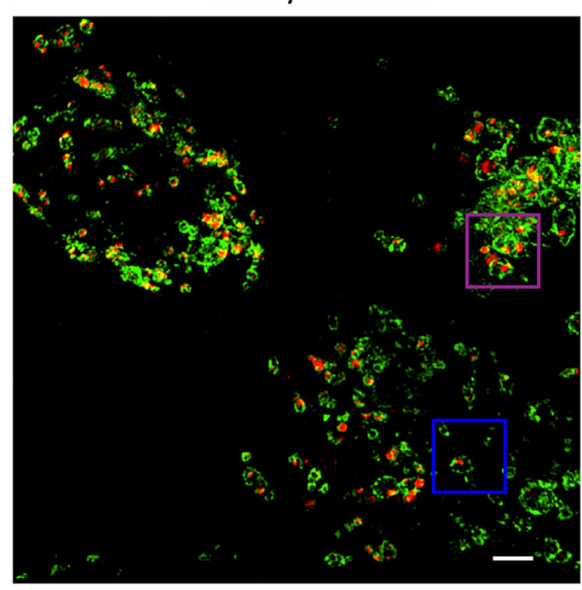

$\mathbf{E}$

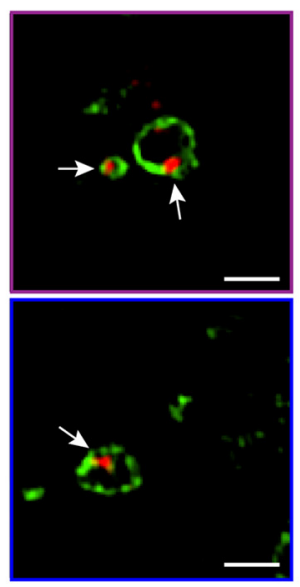

Figure 5. GRNs localize to lysosomes. A, HeLa cells were double immunolabeled with PGRN (R\&D AF2420) and LAMP1 antibodies. $\boldsymbol{B}$, Endogenous HeLa proteins were separated by density-based gradient centrifugation and individual fractions (1-12) were analyzed for PGRN (R\&D AF2420), GRN-2,3 (Sigma), and organelle markers by immunoblot. Results are representative of two independent experiments. C, HAP1 PGRN KO cells were pulse-chased (24-h pulse/6-h chase) with mCherry-PGRN (5 $\mu \mathrm{g} / \mathrm{ml})$ and then double immunolabeled for GRNs (R\&D AF2420) and organelle markers. White arrows indicate colocalization of GRNs and LAMP1. Scale bar, $10 \mu \mathrm{m}$. D, HAP1 GRN KO cells were pulse-chased as in $\boldsymbol{C}$, double immunolabeled for GRNs (R\&D AF2420) and LAMP1, and imaged using Super Resolution microscopy. All z-stacks included. Scale bar, $2 \mu \mathrm{m}$. $\boldsymbol{E}$, Magnified regions of D show that GRNs are mostly found associated with the inner membrane of LAMP1-positive lysosomes (white arrows). Select z-stacks of $\boldsymbol{D}$ shown for clarity. Scale bar, $1 \mu \mathrm{m}$.

TMEM106B, encoding TMEM106B (Van Deerlin et al., 2010; Finch et al., 2011; Nicholson et al., 2013). Thus, we reasoned that altered expression of these proteins would affect the production of intracellular GRNs as well. To address this, we first determined if expression of sortilin, which facilitates endocytosis and trafficking of PGRN to the lysosome (Carrasquillo et al., 2010; Hu et al., 2010), influences GRN levels. We treated PGRN KO cells with PGRN tagged at either the $C$ terminus (C-TAP) (Chen et al., 2013), which disrupts sortilin binding (Zheng et al., 2011) or the $\mathrm{N}$ terminus (N-TAP), which preserves sortilin binding, and measured intracellular PGRN and GRN-2,3 by immunoblot. We found that C-TAP PGRN was not as efficiently endocytosed and processed into GRNs compared to N-TAP PGRN (Fig. 6A), indicating that sortilin plays a major role in the uptake of extracellular PGRN in the HAP1 cell line. Next, we generated HAP1 SORT1 KO cells using CRISPR/Cas9 technology and verified they do not produce sortilin by immunoblot (Fig. 6B). SORT1 KO cells had significantly increased levels of PGRN (Fig. $6 C$ ) and significantly reduced levels of GRN-2,3 (Fig. 6D) compared to WT cells. Thus, disruption of the SORT1/PGRN axis appears to alter intracellular PGRN trafficking to the lysosome, leading to decreased GRN production. Moreover, because genetic deletion of SORT1 did not completely eliminate production of GRN, this data supports that other pathways exist to traffic PGRN to the lysosome as recently reported (Zhou et al., 2015).

Next, we tested if overexpression of the FTD-GRN modifier TMEM106B affects production of GRNs. TMEM106B is a neuronal, lysosomal protein and its overexpression in cells causes lysosomal dysfunction and increased intracellular PGRN levels (Chen-Plotkin et al., 2012; Brady et al., 2013; Stagi et al., 2014; Busch et al., 2016). Notably, 
A

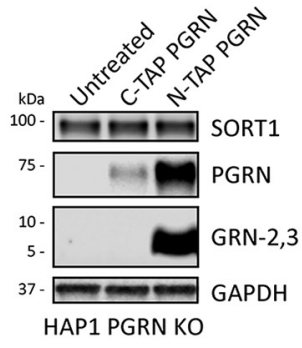

E

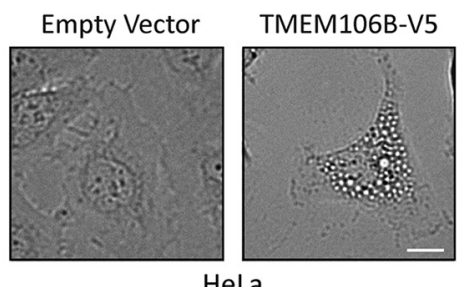

HeLa

J
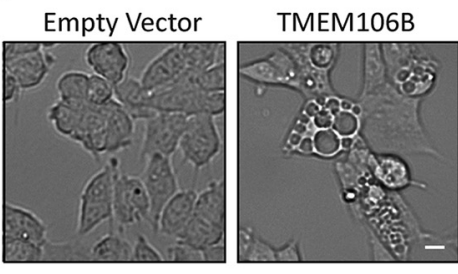

HAP1 PGRN KO
B

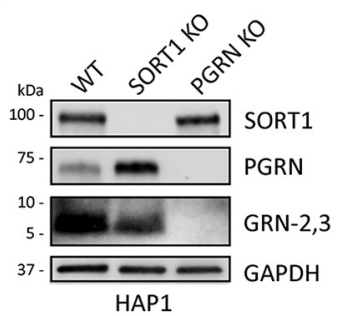

C

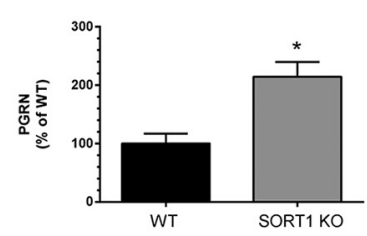

D

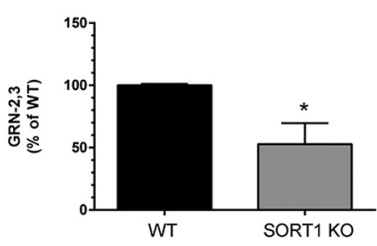

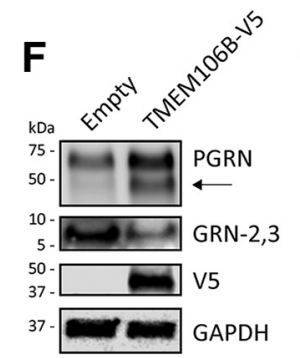

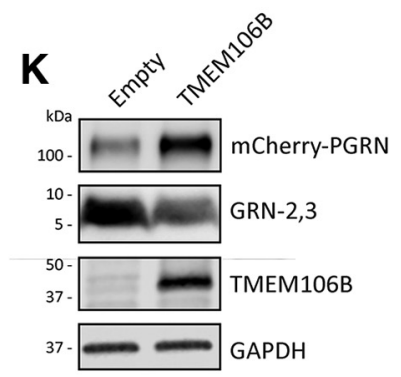

H

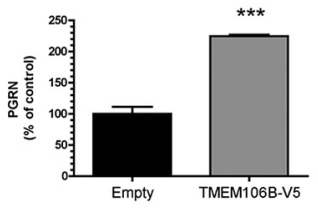

I

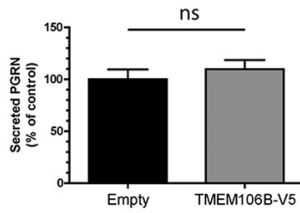

$\mathbf{L}$

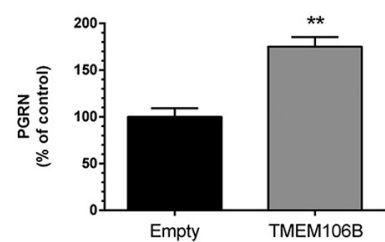

M

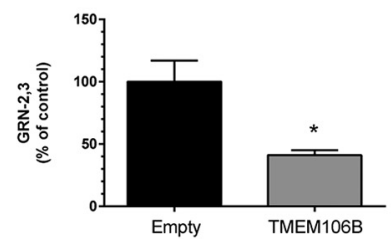

Figure 6. GRN levels are regulated by SORT1 and TMEM106B expression. A, HAP1 PGRN KO cells were treated with C-TAP PGRN or N-TAP PGRN $(5 \mu \mathrm{g} / \mathrm{ml})$ for $24 \mathrm{~h}$ and lysates were analyzed for PGRN and GRN-2,3 by immunoblot. B, HAP1 WT, SORT1 KO, and PGRN KO cell lysates were analyzed for endogenous levels of SORT1, PGRN, and GRN-2,3 by immunoblot. $\boldsymbol{C}, \boldsymbol{D}$, Quantification of (C) PGRN and (D) GRN-2,3 from the experiment in $\boldsymbol{B}$. $\boldsymbol{E}$, Overexpression of TMEM106B in HeLa cells for 48-h results in the formation of large vacuoles. Scale bar, $20 \mu \mathrm{m}$. $\boldsymbol{F}$, HeLa cells were transfected with empty vector or TMEM106B for $48 \mathrm{~h}$ and lysates were analyzed for PGRN and GRN-2,3 by immunoblot. G-I, Quantification of $(\boldsymbol{G})$ intracellular PGRN, $(\boldsymbol{H})$ intracellular $\mathrm{GRN}-2,3$, and $(\boldsymbol{I})$ secreted PGRN (by ELISA) from the experiment in $\boldsymbol{F}$. Arrow in $\boldsymbol{F}$ denotes endogenous, intermediate PGRN cleavage product. $\boldsymbol{J}$, Overexpression of TMEM106B for $24 \mathrm{~h}$ in HAP1 PGRN KO cells results in the formation of large vacuoles. Scale bar, $10 \mu \mathrm{m}$. $\boldsymbol{K}$, HAP1 PGRN KO cells were transfected with TMEM106B for $24 \mathrm{~h}$ and then treated with mCherry-PGRN $(5 \mu \mathrm{g} / \mathrm{ml})$ for an additional $24 \mathrm{~h}$. Lysates were analyzed for PGRN and GRN-2,3 by immunoblot. $\boldsymbol{L}, \boldsymbol{M}$, Quantification of ( $\boldsymbol{L})$ PGRN and $(\boldsymbol{M})$ GRN-2,3 from the experiment in $\boldsymbol{K}$. For all immunoblots, PGRN and GRN-2,3 were detected with R\&D AF2420 and Sigma antibodies, respectively. All immunoblot images are representative of at least three independent experiments and quantitative data are presented as mean \pm SEM of three independent experiments; *differs from control $p<0.05$; $* *<<0.01$; $* * * p<0.001$; ns $=$ not significant.

increased levels of TMEM106B have been found in FTD patient brains (Chen-Plotkin et al., 2012). Here, we transfected TMEM106B into HeLa cells and measured PGRN and GRN-2,3 levels by immunoblot after $48 \mathrm{~h}$. TMEM106B expression resulted in the accumulation of large vacuoles indicative of impaired lysosomal acidification and function (Busch et al., 2016; Fig. 6E) and a significant increase in intracellular PGRN (Fig. 6F,G). Conversely, GRN-2,3 levels were significantly decreased (Fig. $6 F, H$ ). We did not detect any difference in secreted PGRN levels with TMEM106B expression (Fig. 6/), indicating that TMEM106B overexpression likely inhibits intracellular processing of PGRN into GRNs. To assess whether TMEM106B overexpression specifically affects processing of endocytosed PGRN, we transfected PGRN KO cells with TMEM106B for $24 \mathrm{~h}$ and then treated them with mCherry-PGRN for an additional $24 \mathrm{~h}$. Once again, TMEM106B overexpression in HAP1 cells resulted in enlarged vacuoles (Fig. 6J) and significantly reduced processing of endocytosed PGRN into GRN-2,3 (Fig. 6K-M). Together, these data indicate that TMEM106B may increase FTD risk by inhibiting the processing of PGRN into GRNs through lysosome dysfunction or altered trafficking of PGRN.

\section{The processing of PGRN into GRNs is inhibited by pharmacologic lysosome inhibition and cysteine protease inhibitors}

Because we observed the rapid processing of endocytosed PGRN into GRNs, we reasoned that inhibiting lysosome function would impair GRN production. To determine the effect of pharmacologic lysosome inhibition on GRN levels, we treated HAP1 WT cells with the panlysosomal inhibitors chloroquine, BafA1, or concanamycin A1 for $24 \mathrm{~h}$ and monitored PGRN and GRN-2,3 levels 
A

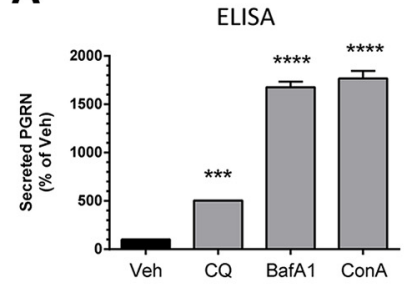

B

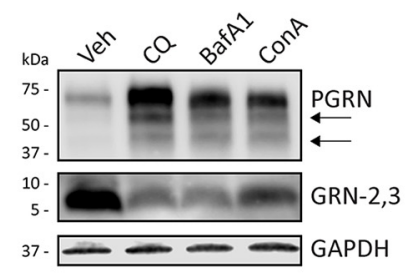

C

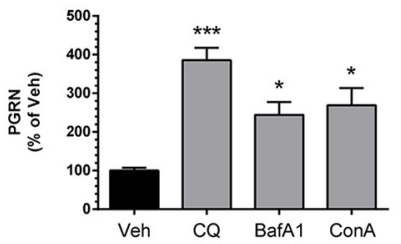

D

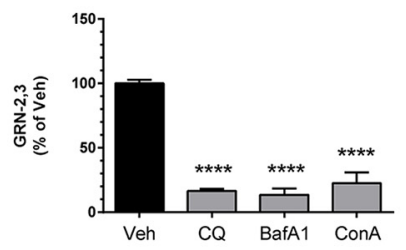

E

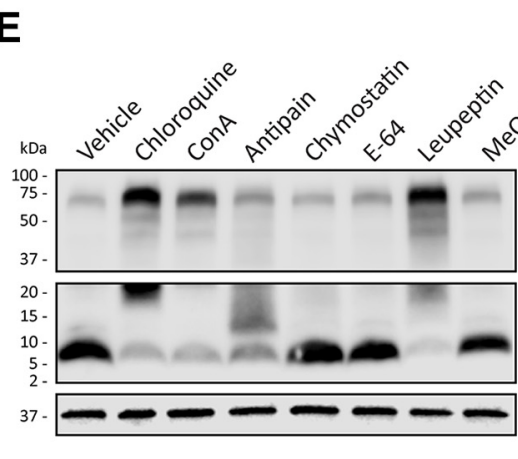

F

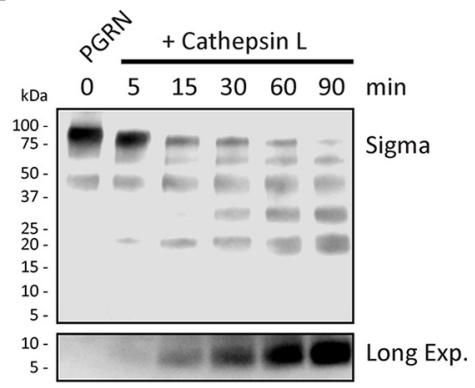

G

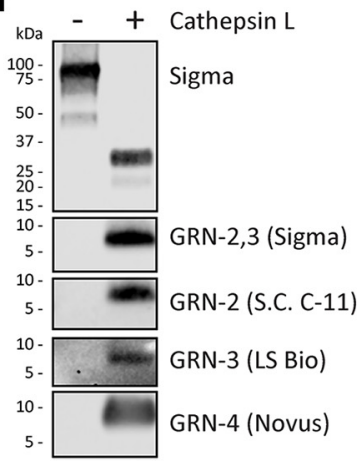

H

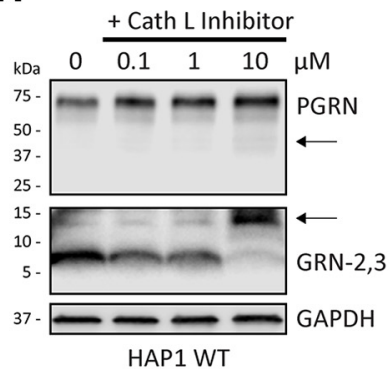

\begin{tabular}{|c|c|c|}
\hline Compound & Target Protease & Concentration \\
\hline Chloroquine & Pan-Lysosomal & $50 \mu \mathrm{M}$ \\
\hline Concanamycin A & Pan-Lysosomal & $50 \mathrm{nM}$ \\
\hline Antipain & Cysteine/Serine & $50 \mu \mathrm{M}$ \\
\hline Chymostatin & Cysteine/Chymotrypsin & $50 \mu \mathrm{M}$ \\
\hline E-64 & Cysteine & $10 \mu \mathrm{M}$ \\
\hline Leupeptin & Cysteine/Serine & $100 \mu \mathrm{M}$ \\
\hline MeOSuC-AAPV-cmk & Elastase & $10 \mu \mathrm{M}$ \\
\hline ALLN & Cysteine & $5 \mu \mathrm{M}$ \\
\hline Aprotinin & Serine & $500 \mathrm{nM}$ \\
\hline Benzamadine HCl & Serine/Trypsin-like & $1 \mathrm{mM}$ \\
\hline EDTA & Metallo & $1 \mathrm{mM}$ \\
\hline Pepstatin & Aspartic & $50 \mu \mathrm{M}$ \\
\hline Z-FA-fmk & Cysteine & $10 \mu \mathrm{M}$ \\
\hline Z-VAD-fmk & Caspases & $10 \mu \mathrm{M}$ \\
\hline
\end{tabular}

I
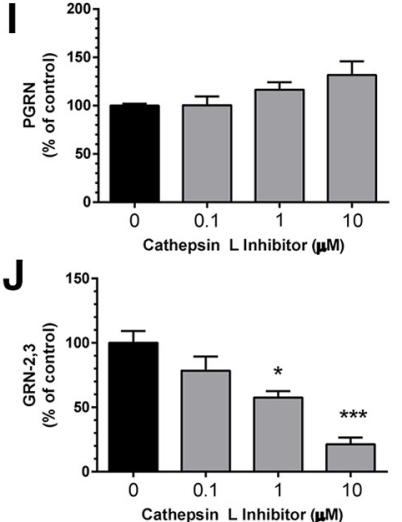

Figure 7. PGRN processing into GRNs is mediated by proper lysosome function and cysteine protease activity. $\boldsymbol{A}$, HAP1 WT cells were treated for $24 \mathrm{~h}$ with the pan-lysosome inhibitors chloroquine $(\mathrm{CQ} ; 50 \mu \mathrm{M})$, BafA1 $(50 \mathrm{nM})$, or concanamycin $\mathrm{A}(\mathrm{ConA} ; 50 \mathrm{nM})$ and conditioned media were analyzed for secreted PGRN by ELISA. $\boldsymbol{B}$, Lysates from HAP1 WT cells treated as in $\boldsymbol{A}$ were analyzed for PGRN and GRN-2,3 by immunoblot. $\boldsymbol{C}, \boldsymbol{D}$, Quantification of $(\boldsymbol{C})$ PGRN and $(\boldsymbol{D}) \mathrm{GRN}-2,3$ from the experiment in $\boldsymbol{B}$. $\boldsymbol{E}$, HAP1 WT cells were treated with the indicated protease inhibitors for $24 \mathrm{~h}$ and analyzed for PGRN and GRN-2,3 by immunoblot. The inhibitors, their primary targets, and concentrations used are shown in the table at right. $\boldsymbol{F}$, Time-dependent cleavage of C-TAP PGRN by recombinant cathepsin L in vitro. $\boldsymbol{G}$, C-TAP PGRN was incubated with or without cathepsin L for $2 \mathrm{~h}$ in vitro and analyzed for multiple GRNs by immunoblot. $\boldsymbol{H}$, HAP1 WT cells were treated with increasing concentrations of cathepsin L inhibitor II (Z-FY-CHO) for $40 \mathrm{~h}$ and lysates were analyzed for PGRN and GRN-2,3 by immunoblot. I, J, Quantification of (I) PGRN and (J) GRN-2,3 from the experiment in $\boldsymbol{H}$. $\boldsymbol{B}, \boldsymbol{E}, \boldsymbol{H}$, Arrows denote endogenous, intermediate PGRN cleavage products. For all immunoblots, PGRN and GRN-2,3 were detected with R\&D AF2420 and Sigma antibodies respectively. All immunoblot images are representative of at least three independent experiments and quantitative data are presented as mean \pm SEM of three independent experiments; *differs from control $p<0.05 ; * * p<0.01 ; * * * p<0.001 ; * * * * p<0.0001$.

by immunoblot. These compounds act as lysosome alkalizing agents or inhibitors of the vacuolar-type $\mathrm{H}+-$ ATPase (V-ATPase), which is needed for proper lysosome acidification and function. Further, these compounds were previously found to robustly increase intracellular and secreted PGRN (Capell et al., 2011). In our experiments, both secreted PGRN (Fig. 7A) and intracellular PGRN (Fig. 7B,C) were significantly increased by all of the pan-lysosomal inhibitors as expected. In contrast, GRN2,3 levels were significantly decreased (Fig. 7B,D), indicating that the processing of PGRN to GRNs was inhibited and depends on the proper acidification and function of lysosomes.
Processing of PGRN into GRNs likely involves one or more lysosomal proteases. To narrow down which class of proteases may be responsible for intracellular PGRN metabolism, we treated HAP1 WT cells with a panel of protease inhibitors and measured PGRN and GRN-2/3 levels by immunoblot. Inhibitors of serine, aspartic, metallo-, or trypsin-like proteases did not affect GRN-2,3 production (Fig. 7E). However, multiple inhibitors of cysteine proteases (antipain, leupeptin, ALLN, and Z-FA-fmk) reduced GRN-2,3 levels compared to vehicle-treated control (Fig. 7E). One potential candidate lysosomal cysteine protease is cathepsin L, which was reported to cleave mouse PGRN in vitro (Park et al., 2011). We found 
A

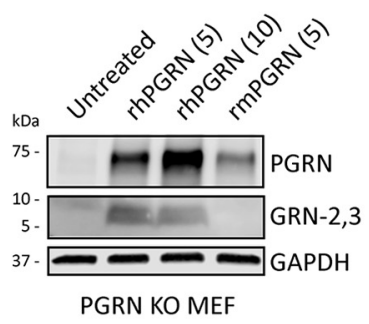

B

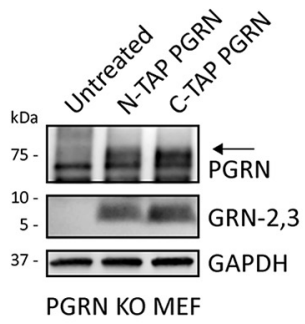

C
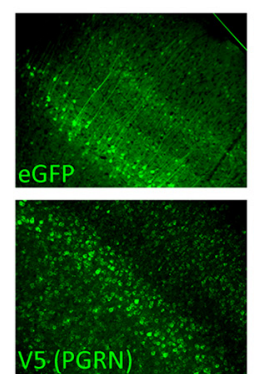
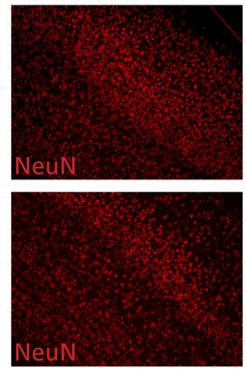
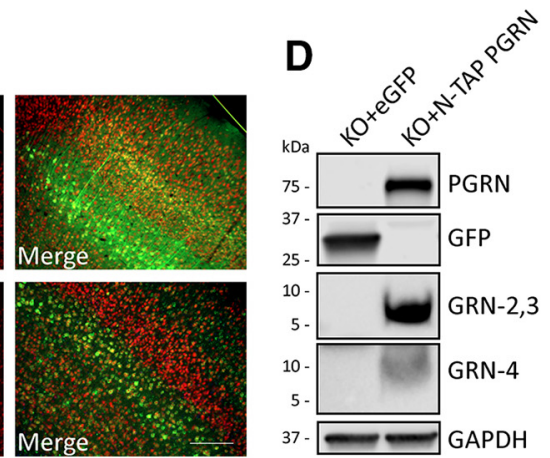

Figure 8. Human PGRN is processed into GRNs in mouse cells and in mouse brain. $\boldsymbol{A}$, PGRN KO MEF cells were treated with recombinant human PGRN (5 or $10 \mu \mathrm{g} / \mathrm{ml}$ ) or recombinant mouse PGRN $(5 \mu \mathrm{g} / \mathrm{ml})$ in the media for $24 \mathrm{~h}$ and lysates were analyzed for PGRN (R\&D AF2420) and GRN-2,3 (Sigma) by immunoblot. R\&D AF2420 displays some cross-reactivity with mouse PGRN. B, PGRN KO MEF cells were treated with N-TAP or C-TAP human PGRN $(5 \mu \mathrm{g} / \mathrm{ml})$ in the media for $24 \mathrm{~h}$ and lysates were analyzed for PGRN and GRN-2,3 by immunoblot. $\boldsymbol{C}$, Cortical sections from three-month-old GRN KO mice injected with AAV2/1-eGFP or AAV2/1-NTAP-PGRN at $P=0$ show colocalization of eGFP or PGRN (V5) expression with the neuronal marker NeuN. Scale bar, 200 $\mu \mathrm{m}$. $\boldsymbol{D}$, Brain tissue lysates from 14-month-old GRN KO mice injected as in C were analyzed for human PGRN (R\&D AF2420) and GRNs (-2,3; Sigma and -4; Novus) by immunoblot. Immunoblots in $\boldsymbol{A}, \boldsymbol{B}$ are representative of two independent experiments each. Images in $\boldsymbol{C}, \boldsymbol{D}$ are representative of at least three independent eGFP- or PGRN-injected mice.

that incubation of cathepsin $L$ and recombinant human PGRN lead to the time-dependent decrease of full-length PGRN and a corresponding increase of GRN-2,3 protein (Fig. 7F). Interestingly, the in vitro cleavage of PGRN by cathepsin $L$ generated multiple, mature GRNs, including GRN-2, GRN-3, and GRN-4 (Fig. 7G). Finally, treatment of HAP1 WT cells with the cathepsin L inhibitor II (Z-FY$\mathrm{CHO}$; Calbiochem) modestly increased endogenous PGRN (Fig. $7 H, I)$, and significantly decreased production of GRN-2,3 (Fig. $7 H, J)$. Overall, these data indicate that properly functioning lysosomes and cysteine proteases in particular contribute to the intracellular processing of PGRN into GRNs.

\section{Human PGRN is processed into mature GRNs in mouse cells and brain}

Because this study focused on screening and validating human-specific PGRN antibodies, we have not yet identified antibodies to detect endogenous mouse GRNs. Nevertheless, we wanted to determine if mouse cells are able to process human PGRN into mature GRNs. To accomplish this goal, we first treated primary PGRN KO MEFs with recombinant human or mouse PGRN for $48 \mathrm{~h}$ and measured PGRN and GRN-2,3 levels in the lysates by immunoblot. PGRN KO MEFs efficiently endocytosed human PGRN and generated mature human GRN-2,3 (Fig. $8 A$ ). The Sigma antibody did not detect any endogenous GRN bands in the PGRN KO MEFs treated with mouse PGRN, confirming that it is specific to human GRNs (Fig. $8 A$ ). Further, PGRN KO MEFs were able to internalize N-TAP or C-TAP human PGRN and generate GRNs equally well (Fig. $8 B$ ), indicating that primary MEFs do not require sortilin for PGRN uptake. Next, we asked if human PGRN would be processed into GRNs when expressed in mouse brain. We performed SBT by injecting rAAV2/1 encoding eGFP or human N-TAP PGRN into the cerebral ventricles of newborn (PO) PGRN KO mice. The SBT paradigm leads to transgene expression that is almost exclusively neuronal (Chakrabarty et al., 2013) as as- sessed by predominant colocalization between eGFP or PGRN (V5) and the neuronal marker NeuN at three months of age (Fig. $8 C$ ). Mice harvested at 14 months of age robustly expressed human PGRN (R\&D AF2420) and produced human GRNs (-2,3; Sigma and -4; Novus) in brain tissue lysates as assessed by immunoblot (Fig. 8D). Taken together, these data demonstrate that the generation of GRNs from PGRN, including the required sorting pathways and protease(s), are conserved between humans and mice.

\section{Multiple GRNs are haploinsufficient in FTD-GRN patient fibroblasts and brain}

Numerous labs have confirmed that PGRN levels are reduced by $\sim 50 \%$ in FTD-GRN patient fibroblasts, brain, serum, and CSF (Gass et al., 2006; Ghidoni et al., 2008; Sleegers et al., 2009; Holler et al., 2016; Meeter et al., 2016), but nothing is known about the relative levels of GRNs in these patients. Using the validated GRNdetecting antibodies from Sigma $(\mathrm{GRN}-2,3)$ and Novus (GRN-4), we first measured mature GRN levels in primary human fibroblasts from three FTD-GRN patients compared with three controls (Fig. 9A). We found that fulllength PGRN (Fig. 9B) as well as GRNs (Fig. 9C,D) were significantly decreased in the FTD-GRN fibroblasts by $\sim 50 \%$, compared to controls. We next assessed GRN levels in soluble lysates of frontal cortex (Brodmann Area 9) brain tissue from five FTD-GRN patients compared to five age-matched controls (Table 4). To determine antibody specificity in brain, we first incubated the entire blots of soluble brain lysates with either the Sigma or Novus antibodies (Fig. 9E). These blots show the same prominent nonspecific bands as in the cell lysates of PGRN KO cells (Fig. 2A), but no specific signals for brain PGRN or GRNs at the expected MWs. Therefore, to eliminate nonspecific protein detection, we cut the membranes around $15 \mathrm{kDa}$ and incubated the bottom sections with the GRN antibodies. Under these conditions, we were able to detect mature GRNs at the expected MWs which were 

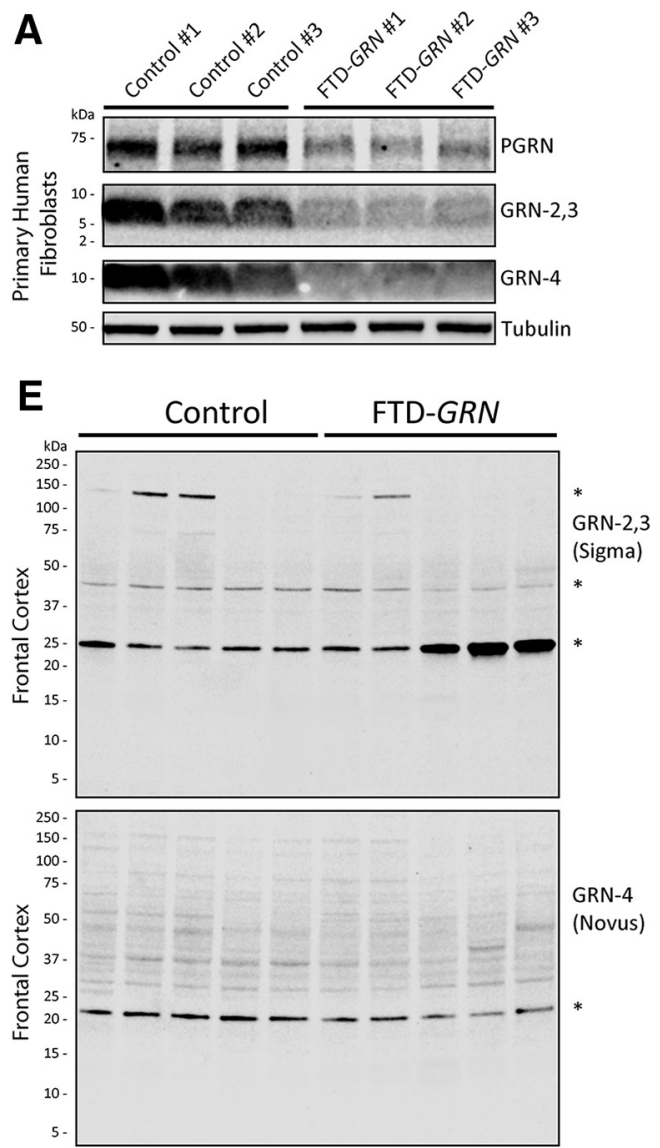

B
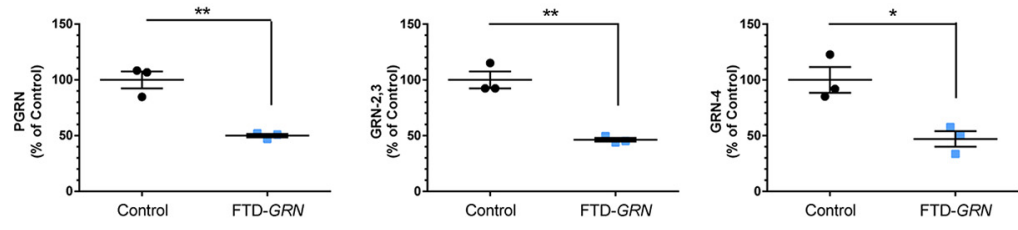

$\mathbf{F}$

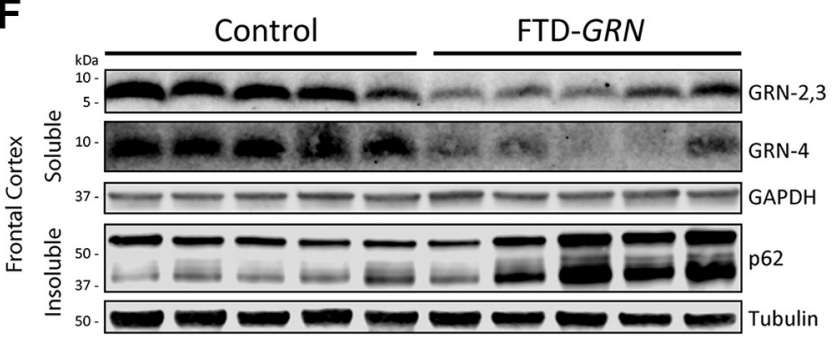

G

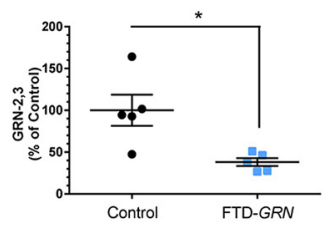

H

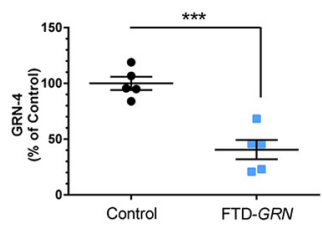

I

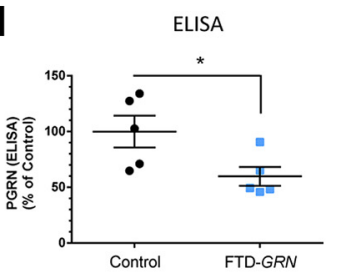

Figure 9. FTD patients with a GRN mutation (FTD-GRN) are haploinsufficient for multiple GRNs. A, Primary fibroblast lysates from three control and three FTD-GRN patients were analyzed for PGRN and GRNs by immunoblot. $\boldsymbol{B}$ - $\boldsymbol{D}$, Quantification of (B) PGRN, (C) GRN-2,3 (Sigma), and (D) GRN-4 (Novus) from the experiment in $\boldsymbol{A}$. $\boldsymbol{E}$, Full-blot images of soluble brain lysates from five control and five FTD-GRN patients using Sigma or Novus anti-GRN antibodies showing predominant nonspecific protein detection (denoted by *). $\boldsymbol{F}$, The same samples from E were run on SDS-PAGE and analyzed for mature GRNs by immunoblot as outlined in Materials and Methods. Immunoblots for insoluble p62 indicate disease-associated pathology in the FTD-GRN cases. G-I, Quantification of (G) GRN-2,3 (Sigma) and $(\boldsymbol{H})$ GRN-4 (Novus) from the experiment in $\boldsymbol{F}$. I, Quantification of PGRN in the same soluble brain lysates from $\mathrm{F}$ by ELISA. All data represent the mean $\pm \mathrm{SEM} ; *$ differs from control $p<0.05 ; * * p<0.01 ; * * * p<0.001$.

significantly reduced by $\sim 60 \%$ compared to controls (Fig. 9F- $H$ ), similar to full-length PGRN, which was reduced by $\sim 40 \%$, as measured by ELISA (Fig. 9/). We also observed increased levels of insoluble p62 in the FTD-GRN cases compared to controls, confirming that these samples were from a disease affected brain region (Fig. 9F). Taken together, these data demonstrate that not only PGRN, but also multiple GRNs, are haploinsufficient in FTD-GRN patients and raise the possibility that deficiency of GRNs in the brain contributes to the underlying pathogenic process leading to neurodegeneration.

\section{Discussion}

In this study, we have identified antibodies that detect multiple human GRNs using a combination of expression and screening assays. Until now, antibody-based detection of endogenous human GRNs has not been reported. Using these tools, we show that mature GRNs are stably produced from intracellular PGRN and localize to LAMP1positive lysosomes. Further, the generation of GRNs from PGRN is inhibited by SORT1 depletion, pan-lysosomal pharmacologic inhibitors, or expression of the FTD-GRN modifier TMEM106B. The proteolytic processing of PGRN into GRNs, mediated in part by cysteine protease activity, is conserved between humans and mice. Finally, we show that endogenous levels of multiple GRNs are haploinsufficient in FTD-GRN patient fibroblasts and frontal cortex, mirroring full-length PGRN.

A major contribution of this study is the development of novel tools and assays for studying human GRNs. First, we have generated constructs for each of the 7.5 human GRN proteins with and without their C-terminal linker regions (Fig. 1A-C; Table 2). Using these constructs, we determined the general epitopes of numerous anti-PGRN antibodies by immunoblot. We identified multiple antibodies that detect individual linker regions of PGRN as well as antibodies that recognize GRN-1, GRN-2, GRN-3, GRN-4, and GRN-5 by reducing immunoblot (Fig. 1E,F). Further, we find that the R\&D AF2420 antibody recognizes all or nearly all overexpressed GRN proteins by immunocytochemistry and nonreducing immunoblot (Fig. 4E). One limitation to the current study is that we were only able to analyze a few GRNs in most experiments due to 


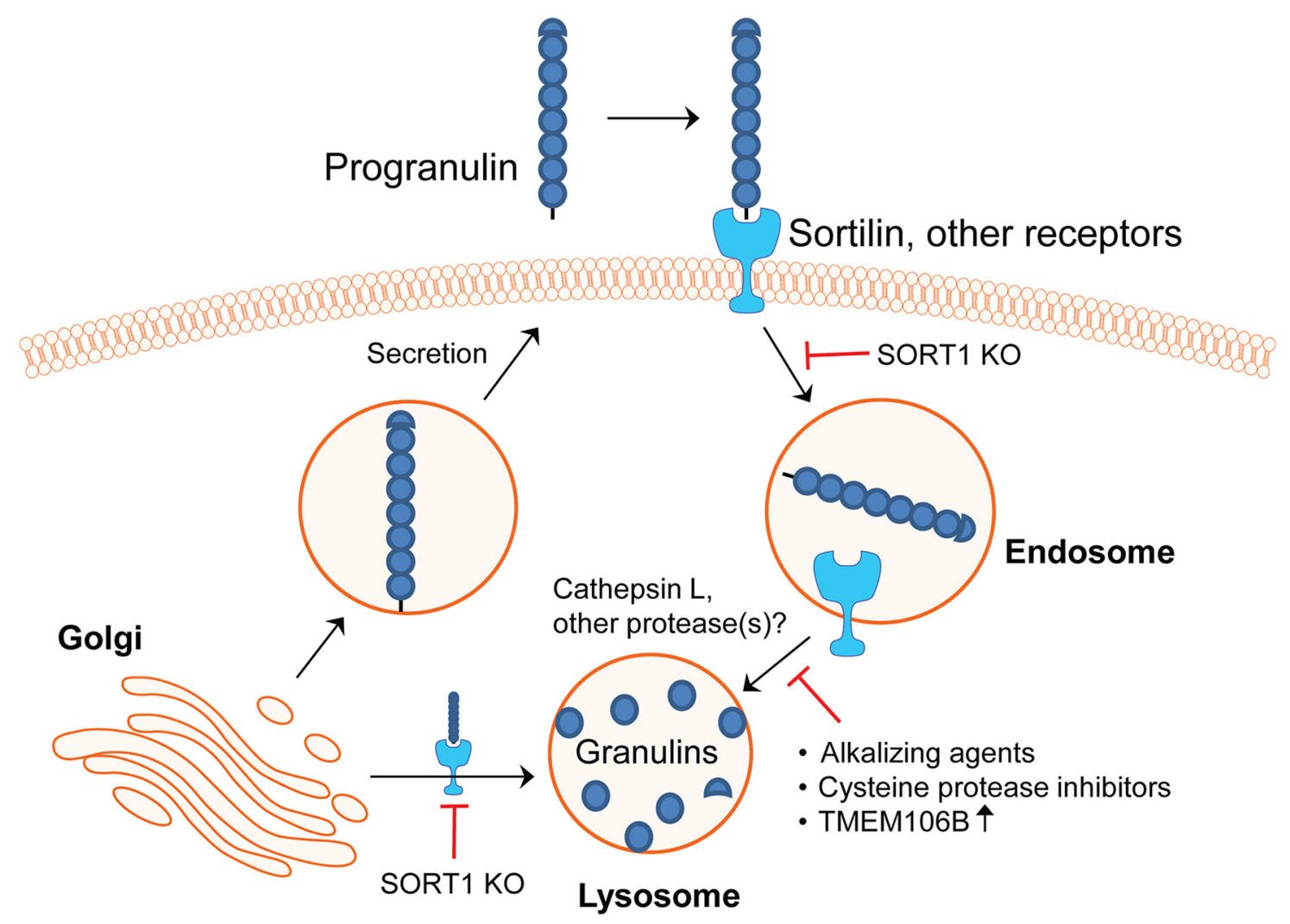

Figure 10. Model of intracellular processing of PGRN into stable, lysosomal GRNs. Sortilin and other receptors target endocytosed and newly synthesized PGRN to lysosomes. Within lysosomes, PGRN is proteolytically cleaved, in part, by cysteine proteases (i.e., cathepsin L) into mature, stable GRN proteins. Ablation of sortilin results in the reduced production of GRNs. Further, lysosome dysfunction caused by alkalizing agents or TMEM106B overexpression inhibits the processing of PGRN into GRNs. FTD-GRN patients are haploinsufficient for GRNs, which may drive lysosome dysfunction leading to neurodegeneration.

the limited sensitivity of some of the antibodies, which could not detect endogenous GRNs (Fig. 2A,B). Alternatively, all GRNs may not be present in cells at comparable levels. Additional higher-affinity antibodies will need to be generated to examine the endogenous expression of all GRN proteins. Second, we have developed a human GRN $\mathrm{KO}$ cell line using CRISPR-Cas9 technology (HAP1 PGRN $\mathrm{KO})$ and a stable cell line that overexpresses human PGRN (HEK-PGRN) to aid in the screening and specificity of PGRN antibodies for detection of GRNs (Fig. 2). These two cell lines are crucial to verify whether antibodies recognize specific PGRN cleavage products. Overall, this suite of tools will allow for more in-depth exploration of expression, localization, and function of GRNs.

In recent years, a critical but unknown role for PGRN in proper lysosome function has emerged. FTD-GRN patients have half the normal levels of PGRN and abnormal accumulation of lysosomal proteins, enzymes, and storage material (Götzl et al., 2014; Ward et al., 2017), which is recapitulated in Grn KO mice (Ahmed et al., 2010; Kleinberger et al., 2010; Yin et al., 2010; Götzl et al., 2014; Tanaka et al., 2014). Further, a mutation in both copies of GRN in humans causes a lysosomal storage disease called NCL (CLN11; Smith et al., 2012; Almeida et al., 2016). Finally, PGRN is shuttled to the lysosome via SORT1 (Hu et al., 2010)- or PSAP (Zhou et al., 2015)dependent pathways in cells and tissue. In this report, we developed a novel PGRN pulse-chase assay to study the generation, localization, and stability of GRNs (Fig. 4). Using antibodies that detect GRNs and our PGRN KO cell line, we have demonstrated that endocytosed PGRN is rapidly processed into mature, stable GRNs that localize to LAMP1-positive lysosomes (Figs. 4, 5), although we cannot rule out that GRNs may also be present in other organelles such as late endosomes. This is in line with the original description of GRNs (also known as epithelins) as heat- and acid-stable proteins that were isolated from cell and tissue lysates (Shoyab et al., 1990). Thus, we provide compelling evidence to test whether individual GRNs regulate critical lysosome functions.

The striking parallels between PGRN and PSAP strengthen our hypothesis for a functional role of GRNs in lysosomes. First, PGRN and PSAP interact with each other (Zhou et al., 2015; Nicholson et al., 2016) and with SORT1 (Lefrancois et al., 2003). PSAP, like PGRN, is processed into smaller lysosomal proteins called saposins (SAPs A, B, C, and D; Misasi et al., 2009). The individual SAPs have critical roles in lysosomal hydrolase activation needed for lipid metabolism and degradation (Schuette et al., 2001; Carvelli et al., 2015). Deficiency in PSAP or individual SAPs leads to several lysosomal storage disorders including Gaucher disease (Tamargo et al., 2012; Motta et al., 2014), Krabbe disease (Spiegel et al., 2005), and metachromatic leukodystrophy (Matsuda 
et al., 2001; Kuchar et al., 2009). Similarly, deficient levels of GRNs may cause lysosomal dysfunction underlying FTD or NCL neurodegeneration. Further work will be needed to determine how PGRN/GRNs and PSAP/SAPs interact and if they share any similar functions in the lysosome.

A recent study suggested that increased production of GRNs may contribute to neurodegenerative disease (Salazar et al., 2015). They report that a $\sim 33$ kDa PGRN intermediate fragment accumulates in diseased regions of Alzheimer's disease (AD) or FTD-TDP patient brains using an antibody generated against GRN-7 (E) (Salazar et al., 2015). This observation could imply a defect in processing of PGRN to fully mature GRNs, possibly caused by lysosome dysfunction. In contrast, we find that PGRN as well as multiple GRNs are decreased by approximately half in both FTD-GRN primary cells and brain tissue (Fig. 9), which is consistent with a reduction in full-length PGRN protein in FTD-GRN disease affected brain regions as reported previously (Chen-Plotkin et al., 2010). Therefore, it is unclear whether a loss of mature GRN proteins, an increase in intermediate GRN fragments, or both, contributes to neurodegeneration. We favor a loss-of-function hypothesis for GRNs, rather than a toxic gain-of-function, because complete loss of GRNs in humans and mice leads to NCL, characterized by severe lysosomal dysfunction and neurodegeneration (Smith et al., 2012; Almeida et al., 2016; Sargeant, 2016). Further research is necessary to clarify the role of full-length PGRN and the individual GRNs in health and disease of the nervous system.

Overall, our study sheds new light on the expression, production, and localization of GRNs using newly identified and developed antibody-based tools (Fig. 10). We find that the endosomal-lysosomal pathway is a major site for the production of GRNs and is dependent on cysteine protease activity. We demonstrate that SORT1 ablation or induction of lysosome dysfunction through TMEM106B expression or pharmacologic lysosome inhibition impairs processing of PGRN into GRNs. Intriguingly, our data also suggest that PGRN is trafficked to the lysosome through additional, unknown pathways based on our observation that a) deletion of SORT1 does not eliminate production of GRNs and b) recombinant PGRN that is unable to bind SORT1 (C-TAP PGRN) is internalized by MEFs and processed into GRNs. Finally, we have found that human PGRN expressed in the mouse brain using rAAV is efficiently processed into GRNs, although we do not know the exact cell types (neurons versus glia) or site (intra or extraceullular) of GRN production in the brain. Nevertheless, the rAAV model will allow future studies to assess the localization and function of human GRNs in the mouse brain until mouse-specific GRN antibodies can be identified or developed. Because lysosome dysfunction is a hallmark of many neurodegenerative diseases, deficient production of GRNs may be a common contributor to the disease process. Indeed, reduced levels of PGRN have been linked to AD (Kelley et al., 2010; Lee et al., 2011; Minami et al., 2014; Sheng et al., 2014; Redaelli et al., 2017) and Parkinson's disease (Chang et al., 2013; Mateo et al., 2013; Van Kampen et al., 2014; Chen et al., 2015). In the future, we will determine the functions of lysosomal GRNs and their therapeutic potential for the treatment of lysosome dysfunction and neurodegeneration.

Note Added in Proof: During the proof stage, it was discovered the labels for Figures $1 \mathrm{E}$ and $\mathrm{F}$ were incorrectly listed in the text and a corrected conflict of interest statement was not included in the Early Release version, published August 9, 2017. The statement and Figure labels have now been corrected.

\section{References}

Ahmed Z, Sheng H, Xu Y-f, Lin W-L, Innes AE, Gass J, Yu X, Hou H, Chiba S, Yamanouchi K, Leissring M, Petrucelli L, Nishihara M, Hutton ML, McGowan E, Dickson DW, Lewis J (2010) Accelerated lipofuscinosis and ubiquitination in granulin knockout mice suggest a role for progranulin in successful aging. Am J Pathol 177: 311-324. CrossRef Medline

Almeida MR, Macário MC, Ramos L, Baldeiras I, Ribeiro MH, Santana I (2016) Portuguese family with the co-occurrence of frontotemporal lobar degeneration and neuronal ceroid lipofuscinosis phenotypes due to progranulin gene mutation. Neurobiol Aging 41:200.e1-200.e5. CrossRef

Almeida S, Zhou L, Gao FB (2011) Progranulin, a glycoprotein deficient in frontotemporal dementia, is a novel substrate of several protein disulfide isomerase family proteins. PLoS One 6:e26454. CrossRef Medline

Baker M, Mackenzie IR, Pickering-Brown SM, Gass J, Rademakers R, Lindholm C, Snowden J, Adamson J, Sadovnick AD, Rollinson S, Cannon A, Dwosh E, Neary D, Melquist S, Richardson A, Dickson D, Berger Z, Eriksen J, Robinson T, Zehr C, et al. (2006) Mutations in progranulin cause tau-negative frontotemporal dementia linked to chromosome 17. Nature 442:916-919. CrossRef Medline

Bang J, Spina S, Miller BL (2015) Frontotemporal dementia. Lancet 386:1672-1682. CrossRef Medline

Bateman A, Belcourt D, Bennett H, Lazure C, Solomon S (1990) Granulins, a novel class of peptide from leukocytes. Biochem Biophys Res Commun 173:1161-1168. Medline

Belcourt DR, Lazure C, Bennett HP (1993) Isolation and primary structure of the three major forms of granulin-like peptides from hematopoietic tissues of a teleost fish (Cyprinus carpio). J Biol Chem 268:9230-9237. Medline

Brady OA, Zheng Y, Murphy K, Huang M, Hu F (2013) The frontotemporal lobar degeneration risk factor, TMEM106B, regulates lysosomal morphology and function. Hum Mol Genet 22:685-695. CrossRef Medline

Busch Jl, Unger TL, Jain N, Tyler Skrinak R, Charan RA, ChenPlotkin AS (2016) Increased expression of the frontotemporal dementia risk factor TMEM106B causes C9orf72-dependent alterations in lysosomes. Hum Mol Genet 25:2681-2697. CrossRef Medline

Canafoglia L, Morbin M, Scaioli V, Pareyson D, D'Incerti L, Fugnanesi V, Tagliavini F, Berkovic SF, Franceschetti S (2014) Recurrent generalized seizures, visual loss, and palinopsia as phenotypic features of neuronal ceroid lipofuscinosis due to progranulin gene mutation. Epilepsia 55:e56-e59. CrossRef Medline

Capell A, Liebscher S, Fellerer K, Brouwers N, Willem M, Lammich S, Gijselinck I, Bittner T, Carlson AM, Sasse F, Kunze B, Steinmetz H, Jansen R, Dormann D, Sleegers K, Cruts M, Herms J, Van Broeckhoven C, Haass C (2011) Rescue of progranulin deficiency associated with frontotemporal lobar degeneration by alkalizing reagents and inhibition of vacuolar ATPase. J Neurosci 31:18851894. CrossRef Medline

Carrasquillo MM, Nicholson AM, Finch N, Gibbs JR, Baker M, Rutherford NJ, Hunter TA, DeJesus-Hernandez M, Bisceglio GD, Mackenzie IR, Singleton A, Cookson MR, Crook JE, Dillman A, Hernandez D, Petersen RC, Graff-Radford NR, Younkin SG, Rade- 
makers R (2010) Genome-wide screen identifies rs646776 near sortilin as a regulator of progranulin levels in human plasma. Am $\mathrm{J}$ Hum Genet 87:890-897. CrossRef Medline

Carvelli L, Libin Y, Morales CR (2015) Prosaposin: a protein with differential sorting and multiple functions. Histol Histopathol 30: 647-660. CrossRef Medline

Chakrabarty P, Rosario A, Cruz P, Siemienski Z, Ceballos-Diaz C, Crosby K, Jansen K, Borchelt DR, Kim J-Y, Jankowsky JL, Golde TE, Levites Y (2013) Capsid serotype and timing of injection determines AAV transduction in the neonatal mice brain. PLoS One 8:e67680. CrossRef Medline

Chang KH, Chen CM, Chen YC, Hsiao YC, Huang CC, Kuo HC, Hsu HC, Lee-Chen GJ, Wu YR (2013) Association between GRN rs5848 polymorphism and Parkinson's disease in Taiwanese population. PLoS One 8:e54448. CrossRef Medline

Chen-Plotkin AS, Xiao J, Geser F, Martinez-Lage M, Grossman M, Unger T, Wood EM, Van Deerlin VM, Trojanowski JQ, Lee VM (2010) Brain progranulin expression in GRN-associated frontotemporal lobar degeneration. Acta Neuropathol 119:111-122. CrossRef Medline

Chen-Plotkin AS, Unger TL, Gallagher MD, Bill E, Kwong LK, Volpicelli-Daley L, Busch Jl, Akle S, Grossman M, Van Deerlin V, Trojanowski JQ, Lee VM (2012) TMEM106B, the risk gene for frontotemporal dementia, is regulated by the microRNA-132/212 cluster and affects progranulin pathways. J Neurosci 32:1121311227. CrossRef

Chen X, Chang J, Deng Q, Xu J, Nguyen TA, Martens LH, Cenik B, Taylor G, Hudson KF, Chung J, Yu K, Yu P, Herz J, Farese RV Jr, Kukar T, Tansey MG (2013) Progranulin does not bind tumor necrosis factor (TNF) receptors and is not a direct regulator of TNF-dependent signaling or bioactivity in immune or neuronal cells. J Neurosci 33:9202-9213. CrossRef

Chen Y, Li S, Su L, Sheng J, Lv W, Chen G, Xu Z (2015) Association of progranulin polymorphism rs5848 with neurodegenerative diseases: a meta-analysis. J Neurol 262:814-822. CrossRef Medline

Cruts M, Gijselinck I, van der Zee J, Engelborghs S, Wils H, Pirici D, Rademakers R, Vandenberghe R, Dermaut B, Martin JJ, van Duijn C, Peeters K, Sciot R, Santens P, De Pooter T, Mattheijssens M, Van den Broeck M, Cuijt I, Vennekens K, De Deyn PP, et al. (2006) Null mutations in progranulin cause ubiquitin-positive frontotemporal dementia linked to chromosome 17q21. Nature 442:920924. CrossRef Medline

Essletzbichler P, Konopka T, Santoro F, Chen D, Gapp BV, Kralovics R, Brummelkamp TR, Nijman SM, Bürckstümmer T (2014) Megabase-scale deletion using CRISPR/Cas9 to generate a fully haploid human cell line. Genome Res 24:2059-2065. CrossRef Medline

Finch N, Baker M, Crook R, Swanson K, Kuntz K, Surtees R, Bisceglio G, Rovelet-Lecrux A, Boeve B, Petersen RC, Dickson DW, Younkin SG, Deramecourt V, Crook J, Graff-Radford NR, Rademakers R (2009) Plasma progranulin levels predict progranulin mutation status in frontotemporal dementia patients and asymptomatic family members. Brain 132:583-591. CrossRef Medline

Finch N, Carrasquillo MM, Baker M, Rutherford NJ, Coppola G, Dejesus-Hernandez M, Crook R, Hunter T, Ghidoni R, Benussi L, Crook J, Finger E, Hantanpaa KJ, Karydas AM, Sengdy P, Gonzalez J, Seeley WW, Johnson N, Beach TG, Mesulam M, et al. (2011) TMEM106B regulates progranulin levels and the penetrance of FTLD in GRN mutation carriers. Neurology 76:467-474. CrossRef Medline

Gass J, Cannon A, Mackenzie IR, Boeve B, Baker M, Adamson J, Crook R, Melquist S, Kuntz K, Petersen R, Josephs K, PickeringBrown SM, Graff-Radford N, Uitti R, Dickson D, Wszolek Z, Gonzalez J, Beach TG, Bigio E, Johnson N, et al. (2006) Mutations in progranulin are a major cause of ubiquitin-positive frontotemporal lobar degeneration. Hum Mol Genet 15:2988-3001. CrossRef Medline

Ghidoni R, Benussi L, Glionna M, Franzoni M, Binetti G (2008) Low plasma progranulin levels predict progranulin mutations in fronto- temporal lobar degeneration. Neurology 71:1235-1239. CrossRef Medline

Ghidoni R, Paterlini A, Albertini V, Binetti G, Benussi L (2012a) Losing protein in the brain: the case of progranulin. Brain Res 1476:172182.

Ghidoni R, Stoppani E, Rossi G, Piccoli E, Albertini V, Paterlini A, Glionna M, Pegoiani E, Agnati LF, Fenoglio C, Scarpini E, Galimberti D, Morbin M, Tagliavini F, Binetti G, Benussi L (2012b) Optimal plasma progranulin cutoff value for predicting null progranulin mutations in neurodegenerative diseases: a multicenter Italian study. Neurodegener Dis 9:121-127.

Götzl JK, Mori K, Damme M, Fellerer K, Tahirovic S, Kleinberger G, Janssens J, van der Zee J, Lang CM, Kremmer E, Martin JJ, Engelborghs S, Kretzschmar HA, Arzberger T, Van Broeckhoven C, Haass C, Capell A (2014) Common pathobiochemical hallmarks of progranulin-associated frontotemporal lobar degeneration and neuronal ceroid lipofuscinosis. Acta Neuropathol 127:845-860. CrossRef Medline

Gowrishankar S, Yuan P, Wu Y, Schrag M, Paradise S, Grutzendler J, De Camilli P, Ferguson SM (2015) Massive accumulation of luminal protease-deficient axonal lysosomes at Alzheimer's disease amyloid plaques. Proc Natl Acad Sci USA 112:E3699-E3708. CrossRef Medline

Holler CJ, Taylor G, McEachin ZT, Deng Q, Watkins WJ, Hudson K, Easley CA, Hu WT, Hales CM, Rossoll W, Bassell GJ, Kukar T (2016) Trehalose upregulates progranulin expression in human and mouse models of GRN haploinsufficiency: a novel therapeutic lead to treat frontotemporal dementia. Mol Neurodegener 11:46. CrossRef Medline

Hrabal R, Chen Z, James S, Bennett HP, Ni F (1996) The hairpin stack fold, a novel protein architecture for a new family of protein growth factors. Nat Struct Biol 3:747-752. Medline

Hu F, Padukkavidana T, Vægter CB, Brady OA, Zheng Y, Mackenzie IR, Feldman HH, Nykjaer A, Strittmatter SM (2010) Sortilinmediated endocytosis determines levels of the frontotemporal dementia protein, progranulin. Neuron 68:654-667. CrossRef Medline

Kelley BJ, Haidar W, Boeve BF, Baker M, Shiung M, Knopman DS, Rademakers R, Hutton M, Adamson J, Kuntz KM, Dickson DW, Parisi JE, Smith GE, Petersen RC (2010) Alzheimer disease-like phenotype associated with the c.154delA mutation in progranulin. Arch Neurol 67:171-177. CrossRef Medline

Kessenbrock K, Fröhlich L, Sixt M, Lämmermann T, Pfister H, Bateman A, Belaaouaj A, Ring J, Ollert M, Fässler R, Jenne DE (2008) Proteinase 3 and neutrophil elastase enhance inflammation in mice by inactivating antiinflammatory progranulin. $\mathrm{J}$ Clin Invest 118:2438-2447. CrossRef Medline

Kleinberger G, Capell A, Haass C, Van Broeckhoven C (2013) Mechanisms of granulin deficiency: lessons from cellular and animal models. Mol Neurobiol 47:337-360. CrossRef Medline

Kleinberger G, Wils H, Ponsaerts $P$, Joris G, Timmermans J-P, Van Broeckhoven C, Kumar-Singh S (2010) Increased caspase activation and decreased TDP-43 solubility in progranulin knockout cortical cultures. J Neurochem 115:735-747. CrossRef Medline

Kollmann K, Mutenda KE, Balleininger M, Eckermann E, von Figura K, Schmidt B, Lübke T (2005) Identification of novel lysosomal matrix proteins by proteome analysis. Proteomics 5:3966-3978. CrossRef Medline

Kuchar L, Ledvinová J, Hrebícek M, Mysková H, Dvoráková L, Berná L, Chrastina P, Asfaw B, Elleder M, Petermöller M, Mayrhofer H, Staudt M, Krägeloh-Mann I, Paton BC, Harzer K (2009) Prosaposin deficiency and saposin B deficiency (activator-deficient metachromatic leukodystrophy): report on two patients detected by analysis of urinary sphingolipids and carrying novel PSAP gene mutations. Am J Med Genet A 149A:613-621. CrossRef Medline

Lee MJ, Chen TF, Cheng TW, Chiu MJ (2011) rs5848 variant of progranulin gene is a risk of Alzheimer's disease in the Taiwanese population. Neurodegener Dis 8:216-220. CrossRef Medline 
Lefrancois S, Zeng J, Hassan AJ, Canuel M, Morales CR (2003) The lysosomal trafficking of sphingolipid activator proteins (SAPs) is mediated by sortilin. EMBO J 22:6430-6437. CrossRef Medline

Lui H, Zhang J, Makinson SR, Cahill MK, Kelley KW, Huang HY, Shang Y, Oldham MC, Martens LH, Gao F, Coppola G, Sloan SA, Hsieh CL, Kim CC, Bigio EH, Weintraub S, Mesulam MM, Rademakers R, Mackenzie IR, Seeley WW, et al. (2016) Progranulin deficiency promotes circuit-specific synaptic pruning by microglia via complement activation. Cell 165:921-935. CrossRef Medline

Mackenzie IR, Neumann M (2017) Reappraisal of TDP-43 pathology in FTLD-U subtypes. Acta Neuropathol 134:79-96. CrossRef Medline

Martini-Stoica H, Xu Y, Ballabio A, Zheng H (2016) The autophagylysosomal pathway in neurodegeneration: a TFEB perspective. Trends Neurosci 39:221-234. CrossRef Medline

Mateo I, González-Aramburu I, Pozueta A, Vázquez-Higuera JL, Rodríguez-Rodríguez E, Sánchez-Juan P, Calero M, Dobato JL, Infante J, Berciano J, Combarros O (2013) Reduced serum progranulin level might be associated with Parkinson's disease risk. Eur J Neurol 20:1571-1573. CrossRef

Matsuda J, Vanier MT, Saito Y, Tohyama J, Suzuki K, Suzuki K (2001) A mutation in the saposin A domain of the sphingolipid activator protein (prosaposin) gene results in a late-onset, chronic form of globoid cell leukodystrophy in the mouse. Hum Mol Genet 10: 1191-1199. CrossRef

Meeter LH, Patzke H, Loewen G, Dopper EG, Pijnenburg YA, van Minkelen R, van Swieten JC (2016) Progranulin levels in plasma and cerebrospinal fluid in granulin mutation carriers. Dement Geriatr Cogn Dis Extra 6:330-340. CrossRef Medline

Minami SS, Min S-W, Krabbe G, Wang C, Zhou Y, Asgarov R, Li Y, Martens LH, Elia LP, Ward ME, Mucke L, Farese RV Jr, Gan L (2014) Progranulin protects against amyloid $\beta$ deposition and toxicity in Alzheimer's disease mouse models. Nat Med 20:11571164. CrossRef

Misasi R, Hozumi I, Inuzuka T, Capozzi A, Mattei V, Kuramoto Y, Shimeno H, Soeda S, Azuma N, Yamauchi T, Hiraiwa M (2009) Biochemistry and neurobiology of prosaposin: a potential therapeutic neuro-effector. Cent Nerv Syst Agents Med Chem 9:119131. Medline

Motta M, Camerini S, Tatti M, Casella M, Torreri P, Crescenzi M, Tartaglia M, Salvioli R (2014) Gaucher disease due to saposin C deficiency is an inherited lysosomal disease caused by rapidly degraded mutant proteins. Hum Mol Genet 23:5814-5826. CrossRef Medline

Nicholson AM, Rademakers R (2016) What we know about TMEM106B in neurodegeneration. Acta Neuropathol 132:639651. CrossRef Medline

Nicholson AM, Finch NA, Wojtas A, Baker MC, Perkerson RB 3rd, Castanedes-Casey M, Rousseau L, Benussi L, Binetti G, Ghidoni R, Hsiung GY, Mackenzie IR, Finger E, Boeve BF, Ertekin-Taner N, Graff-Radford NR, Dickson DW, Rademakers R (2013) TMEM106B p.T185S regulates TMEM106B protein levels: implications for frontotemporal dementia. J Neurochem 126:781-791. CrossRef

Nicholson AM, Finch NA, Almeida M, Perkerson RB, van Blitterswijk M, Wojtas A, Cenik B, Rotondo S, Inskeep V, Almasy L, Dyer T, Peralta J, Jun G, Wood AR, Frayling TM, Fuchsberger C, Fowler S, Teslovich TM, Manning AK, Kumar S, et al. (2016) Prosaposin is a regulator of progranulin levels and oligomerization. Nat Commun 7:11992. CrossRef Medline

Park B, Buti L, Lee S, Matsuwaki T, Spooner E, Brinkmann MM, Nishihara M, Ploegh HL (2011) Granulin is a soluble cofactor for toll-like receptor 9 signaling. Immunity 34:505-513. CrossRef Medline

Platt FM, Boland B, van der Spoel AC (2012) The cell biology of disease: Iysosomal storage disorders: the cellular impact of lysosomal dysfunction. J Cell Biol 199:723-734. CrossRef Medline

Pottier C, Ravenscroft TA, Sanchez-Contreras M, Rademakers R (2016) Genetics of FTLD: overview and what else we can expect from genetic studies. J Neurochem 138 [Suppl 1]:32-53.
Redaelli V, Rossi G, Maderna E, Kovacs GG, Piccoli E, Caroppo P, Cacciatore F, Spinello S, Grisoli M, Sozzi G, Salmaggi A, Tagliavini F, Giaccone G (2017) Alzheimer neuropathology without frontotemporal lobar degeneration hallmarks (TAR DNA-binding protein 43 inclusions) in missense progranulin mutation Cys139Arg. Brain Pathology. CrossRef

Ryan C, Baranowski D, Chitramuthu B, Malik S, Li Z, Cao M, Minotti S, Durham H, Kay D, Shaw C, Bennett H, Bateman A (2009) Progranulin is expressed within motor neurons and promotes neuronal cell survival. BMC Neurosci 10:130. CrossRef Medline

Salazar DA, Butler VJ, Argouarch AR, Hsu T-Y, Mason A, Nakamura A, McCurdy H, Cox D, Ng R, Pan G, Seeley WW, Miller BL, Kao AW (2015) The progranulin cleavage products, granulins, exacerbate TDP-43 toxicity and increase TDP-43 levels. J Neurosci 35:93159328. CrossRef Medline

Sargeant TJ (2016) Commentary: possible involvement of lysosomal dysfunction in pathological changes of the brain in aged progranulin-deficient mice. Front Aging Neurosci 8:11. CrossRef Medline

Schuette CG, Pierstorff B, Huettler S, Sandhoff K (2001) Sphingolipid activator proteins: proteins with complex functions in lipid degradation and skin biogenesis. Glycobiology 11:81r-90r. Medline

Settembre C, Di Malta C, Polito VA, Arencibia MG, Vetrini F, Erdin S, Erdin SU, Huynh T, Medina D, Colella P, Sardiello M, Rubinsztein DC, Ballabio A (2011) TFEB links autophagy to lysosomal biogenesis. Science 332:1429-1433. CrossRef

Sheng J, Su L, Xu Z, Chen G (2014) Progranulin polymorphism rs5848 is associated with increased risk of Alzheimer's disease. Gene 542:141-145. CrossRef Medline

Shoyab M, McDonald VL, Byles C, Todaro GJ, Plowman GD (1990) Epithelins 1 and 2: isolation and characterization of two cysteinerich growth-modulating proteins. Proc Natl Acad Sci USA 87: 7912-7916. Medline

Sleegers K, Brouwers N, Van Damme P, Engelborghs S, Gijselinck I, van der Zee J, Peeters K, Mattheijssens M, Cruts M, Vandenberghe R, De Deyn PP, Robberecht W, Van Broeckhoven C (2009) Serum biomarker for progranulin-associated frontotemporal lobar degeneration. Ann Neurol 65:603-609. CrossRef Medline

Smith KR, Damiano J, Franceschetti S, Carpenter S, Canafoglia L, Morbin M, Rossi G, Pareyson D, Mole SE, Staropoli JF, Sims KB, Lewis J, Lin WL, Dickson DW, Dahl HH, Bahlo M, Berkovic SF (2012) Strikingly different clinicopathological phenotypes determined by progranulin-mutation dosage. Am J Hum Genet 90: 1102-1107. CrossRef Medline

Song W, Wang F, Savini M, Ake A, di Ronza A, Sardiello M, Segatori L (2013) TFEB regulates lysosomal proteostasis. Hum Mol Genet 22:1994-2009. CrossRef Medline

Songsrirote K, Li Z, Ashford D, Bateman A, Thomas-Oates J (2010) Development and application of mass spectrometric methods for the analysis of progranulin $\mathrm{N}$-glycosylation. J Proteomics 73: 1479-1490. CrossRef Medline

Spiegel R, Bach G, Sury V, Mengistu G, Meidan B, Shalev S, Shneor $Y$, Mandel H, Zeigler M (2005) A mutation in the saposin A coding region of the prosaposin gene in an infant presenting as Krabbe disease: first report of saposin A deficiency in humans. Mol Genet Metab 84:160-166.

Stagi M, Klein ZA, Gould TJ, Bewersdorf J, Strittmatter SM (2014) Lysosome size, motility and stress response regulated by frontotemporal dementia modifier TMEM106B. Mol Cell Neurosci 61: 226-240. CrossRef Medline

Suh H-S, Choi N, Tarassishin L, Lee SC (2012) Regulation of progranulin expression in human microglia and proteolysis of progranulin by matrix metalloproteinase-12 (MMP-12). PLoS One 7:e35115. CrossRef Medline

Tamargo RJ, Velayati A, Goldin E, Sidransky E (2012) The role of saposin C in Gaucher disease. Mol Genet Metab 106:257-263. CrossRef Medline

Tanaka Y, Chambers JK, Matsuwaki T, Yamanouchi K, Nishihara M (2014) Possible involvement of lysosomal dysfunction in patholog- 
ical changes of the brain in aged progranulin-deficient mice. Acta Neuropathol Commun 2:78. CrossRef Medline

Tolkatchev D, Malik S, Vinogradova A, Wang P, Chen Z, Xu P, Bennett HP, Bateman A, Ni F (2008) Structure dissection of human progranulin identifies well-folded granulin/epithelin modules with unique functional activities. Protein Sci 17:711-724. CrossRef

Uhlen M, Bandrowski A, Carr S, Edwards A, Ellenberg J, Lundberg E, Rimm DL, Rodriguez H, Hiltke T, Snyder M, Yamamoto T (2016) A proposal for validation of antibodies. Nat Methods 13:823-827. CrossRef Medline

Uhlén M, Fagerberg L, Hallström BM, Lindskog C, Oksvold P, Mardinoglu A, Sivertsson Å, Kampf C, Sjöstedt E, Asplund A, Olsson I, Edlund K, Lundberg E, Navani S, Szigyarto CA, Odeberg J, Djureinovic D, Takanen JO, Hober S, Alm T, et al. (2015) Tissue-based map of the human proteome. Science 347:1260419. CrossRef

Van Deerlin VM, Sleiman PM, Martinez-Lage M, Chen-Plotkin A, Wang LS, Graff-Radford NR, Dickson DW, Rademakers R, Boeve BF, Grossman M, Arnold SE, Mann DM, Pickering-Brown SM, Seelaar H, Heutink P, van Swieten JC, Murrell JR, Ghetti B, Spina S, Grafman J, et al. (2010) Common variants at 7p21 are associated with frontotemporal lobar degeneration with TDP-43 inclusions. Nat Genet 42:234-239. CrossRef Medline

Van Kampen JM, Baranowski D, Kay DG (2014) Progranulin gene delivery protects dopaminergic neurons in a mouse model of Parkinson's disease. PLoS One 9:e97032. CrossRef

Ward ME, Chen R, Huang HY, Ludwig C, Telpoukhovskaia M, Taubes A, Boudin H, Minami SS, Reichert M, Albrecht P, Gelfand JM, Cruz-Herranz A, Cordano C, Alavi MV, Leslie S, Seeley WW, Miller BL, Bigio E, Mesulam MM, Bogyo MS, et al. (2017) Individ- uals with progranulin haploinsufficiency exhibit features of neuronal ceroid lipofuscinosis. Sci Transl Med 9.

Wils H, Kleinberger G, Pereson S, Janssens J, Capell A, Van Dam D, Cuijt I, Joris G, De Deyn PP, Haass C, Van Broeckhoven C, Kumar-Singh S (2012) Cellular ageing, increased mortality and FTLD-TDP-associated neuropathology in progranulin knockout mice. J Pathol 228:67-76. CrossRef Medline

Yin F, Dumont M, Banerjee R, Ma Y, Li H, Lin MT, Beal MF, Nathan C, Thomas B, Ding A (2010) Behavioral deficits and progressive neuropathology in progranulin-deficient mice: a mouse model of frontotemporal dementia. FASEB J 24:4639-4647. CrossRef Medline

Zhang Y, Sloan Steven A, Clarke Laura E, Caneda C, Plaza Colton A, Blumenthal Paul D, Vogel H, Steinberg Gary K, Edwards Michael SB, Li G, Duncan John A, III, Cheshier Samuel H, Shuer Lawrence M, Chang Edward F, Grant Gerald A, Gephart Melanie GH, Barres Ben A (2016) Purification and characterization of progenitor and mature human astrocytes reveals transcriptional and functional differences with mouse. Neuron 89:37-53.

Zheng Y, Brady OA, Meng PS, Mao Y, Hu F (2011) C-terminus of progranulin interacts with the beta-propeller region of sortilin to regulate progranulin trafficking. PLoS One 6:e21023. CrossRef Medline

Zhou X, Sun L, Bastos de Oliveira F, Qi X, Brown WJ, Smolka MB, Sun Y, Hu F (2015) Prosaposin facilitates sortilin-independent lysosomal trafficking of progranulin. J Cell Biol 210:991-1002. CrossRef Medline

Zhu J, Nathan C, Jin W, Sim D, Ashcroft GS, Wahl SM, Lacomis L, Erdjument-Bromage H, Tempst P, Wright CD, Ding A (2002) Conversion of proepithelin to epithelins: roles of SLPI and elastase in host defense and wound repair. Cell 111:867-878. Medline 